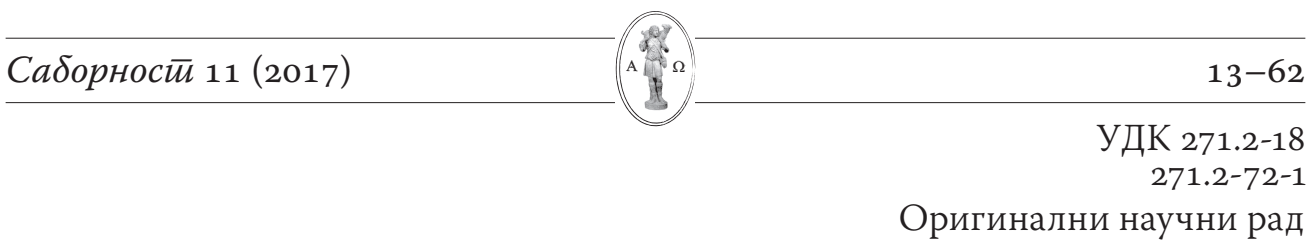

\title{
Игнатије Мидић"
}

Универзитет у Београду, Православни богословски факултет, Београд

\section{За један другачији начин живота}

\begin{abstract}
: Савремени начин живота донео је човеку многе велике проблеме. Прети да угрози само постојање, како човека, тако и природе. Да ли је савремени начин постојања човека и читаве твари, живот према логици савремене цивилизације, уједно и једини могући? Има ли алтернативе? Ко треба да понуди ту алтернативу? У овој студији аутор развија тезу о томе да је управо Црква та реалност која може да понуди алтернативу, нови начин пројаве живота данас.
\end{abstract}

Key words: савремена цивилизација, Црква, Литургија, Христос, заједница есхатологија.

Casti

авремени начин живота донео је човеку многе велике проблеме. Прети да угрози само постојање, како човека, тако и природе. Да ли је савремени начин постојања човека и читаве твари, живот према логици савремене цивилизације, уједно и једини могући? Има ли алтернативе? Ко треба да понуди ту алтернативу? У овој студији покушаћемо да развијемо тезу о томе да је управо Црква та реалност која може да понуди алтернативу, нови начин пројаве живота данас.

У савременом свету Црква је апсолутно на маргинама друштвених збивања зато што многи мисле да савремена европска цивилизација нема потребе данас за Црквом и њеном теологијом у решавању својих кључних проблема. Тамо где Црква има неког значаја то је најчешће због њене улоге у прошлости око одржања националног идентитета тог народа.

Они људи који и „верују у Бога“ у већини случајева не могу да објасне ни себи ни другима зашто је за то потребна Црква. Тако, дакле, многи наши савременици мисле да Црква и њена теологија нису потребне ни онима који верују, а још мање онима који не верују у Бога. Колико је ово мишљење тачно? Колико и у којим сегментима може православље да утиче на човека савремене евроатлантске цивилизације у решавању проблема с којима се он данас суочава? Да ли неко може истински да верује у Бога мимо Цркве, односно да није члан Цркве? Шта је у крајњем случају Црква и зашто је она

\footnotetext{
•spcbran@ptt.rs
} 
потребна свету? Да бисмо могли да одговоримо на постављена питања, морамо најпре да видимо шта је савремена цивилизација и где су њене проблематичне тачке? Затим ћемо видети у којој мери и у којим сегментима може православље да допринесе решавању проблема савременог човека.

Пре него почнем са излагањем свог виђења савремене цивилизације, желео бих да подвучем да је критичка анализа савремене европске цивилизације огромна тема и зато није могуће дати заокружен одговор у вези с њом. Посебно то није могуће у оквиру једне кратке и тематски уске теолошке студије каква је ова наша. Зато ћу покушати да означим само основне елементе који карактеришу савремену цивилизацију, као и проблеме које ти елементи стварају у односу на живот, а посебно у односу на Цркву, с надом да ће ова тема бити ускоро предмет изучавања и других наука, а не само теологије, посебно због тога што она има несагледиве последице за даљу судбину, не само хришћанске Цркве у њој, већ и постојања света уопште ${ }^{1}$. Речју, критичка анализа савремене цивилизације и њених корена послужиће нам овде за проналажење одговора на питања: каква је улога Православне Цркве у решавању појединих проблема савременог друштва, и на који начин треба да делује Црква у савременом друштву да би сачувала свој идентитет, тј. да се не би секуларизовала?

Нема сумње да се корени савремене европске цивилизације налазе на Западу, у такозваном ромејском, римском предању. Овом предању додато је јелинско наслеђе посредством блаженог Августина и каснијих његових следбеника, али протумачено у оквирима хришћанског учења. Речју, савремена европска цивилизација створена је као синтеза латинско-јелинског погледа на свет и живот и схватања Бога и човека од стране западних средњовековних хришћанских мислилаца, почевши од блаженог Августина. Допринос Августинов се састоји у томе што је он покушао да христијанизује јелинску философију у њеним кључним појмовима са циљем да је искористи као помоћно средство у тумачењу основних хришћанских истина и њиховог преношења ученим Латинима свога времена. Тај подухват је учинио да Августин постане отац савремене европске мисли на којој је утемељена и савремена цивилизација. Ако извучемо Августина из грађевине коју називамо савремена цивилизација, читава грађевина ће одмах пасти. Пре него што видимо у чему је специфичан допринос блаженог Августина у стварању савремене цивилизације, хајде да се кратко осврнемо на ромејско предање пре хришћанства.

Опште је познато да западни став према свету и животу, кога су изражавали Латини који су живели на тлу данашње северне Африке и Рима,

1 Парцијалне критичке анализе савремене цивилизације у контексту неких проблема су се

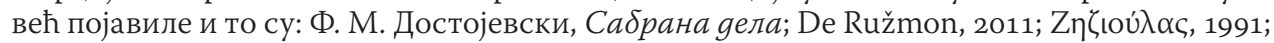
такође види: Мидић, 2009, и др. Међутим, потребна је једна опсежна систематска студија из других области како би се стекла целовита слика о свету у коме живимо. 
карактерише брига за оріанизацијом, за организовањем бића како би она могла бити уйойребљива, тј. корисна. Ово је резултирало фантастичном организацијом институција и, на крају, државе, док је на пољу мишљења и философије имало друге, много дубље последице. Да би бића била прикладна за организовање, разврставање и употребу, морала су да буду на неки начин чврста, статична, односно била је потребна објекйивизација бића. Дакле, две кључне карактерне особине латинског погледа на свет које је наследила и савремена, а посебно наша европска цивилизација јесу:

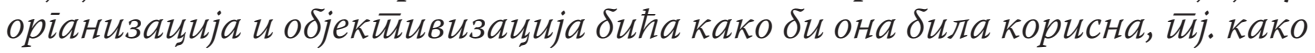

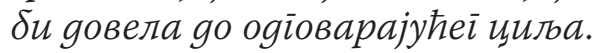

Сви кључни елементи који карактеришу јелински животни став, као што су природа као потка истинског постојања, затим Логос који уређује свет и тако даље, ушли су у то такозвано западно, тј. ромејско предање посредством блаженог Августина. Међутим, све оно што је стара јелинска мисао изнедрила као животни став, тј. као став према свету, а што је ушло у западну цивилизацију, морало је да се уклопи у ова два кључна латинска става: у организацију и објективизацију. То уклапање у овај оквир довело је и до трансформације ових кључних појмова. Тако на пример, јелинско схватање природе (Фи́бı), која је била за Јелине једна од кључних истина, само ठиће, ипостас свега што постоји, а која је изражавала једно динамичко и перманентно развијање, за Латине је постала „натура“, више статична и објективна стварност. (Реч стварност у нашем језику, али не само у нашем, у свом корену има ствар, па је читава природа као стварност постала ствар, и зато је ствар једина стварност и истина у савременој цивилизацији). Исти је случај са јелинским појмом Логос, који је такође једна од кључних истина старих Јелина, а који је у односу на постојање, на природу, изражавао једно чудесно јединство свега што постоји (бv $\lambda \dot{\varepsilon} \gamma \omega)$ и на тај начин је свет за Јелине био космос, савршенство хармоније и лепоте, за Запад је постао појам логичности, тј. сила ума којом се свет разједињује, анализира да би се касније организовао како би био користан, односно искоришћен. Захваљујући оваквом схватању природе и логоса од стране блаженог Августина, дошла је касније као последица апсолутна доминација разума, односно логике над постојањем, над природом, тј. дошло је до стварања европског рационализма на коме ће се утемељити целокупни живот савремене цивилизације. Као последица рационалног, тј. логичког приступа животу, дошло је до развоја науке као логичког истраживања и анализе природе као објекта. Да би се резултати научног истраживања искористили у животу човека савремени свет је упоредо са науком развијао и технику. У том споју између науке и технике дошло је до стварања технологије у савременој цивилизацији која је стављена у службу човека ради употребе, тачније искоришћавања природе у циљу остварења среће за човека. 
Посебни допринос Августина у стварању савремене цивилизације огледа се у схватању човека и увођењу појма личности, тј. дефиниције човека, односно Бога као личности, што је типично хришћански појам. Настао је у напору да се објасни хришћанска вера у Бога који је један али у исто време и Тројичан, тј. Света Тројица као један Бог. И управо Августиново увођење појма личности као дефиниције човека у западну културу, представља кључну тачку савремене европске мисли и савремене европске цивилизације уопште, али и кључни проблем из кога ће се развити сви остали проблеми с којим се данас сусреће савремени човек, па и проблеми у вези са Црквом, тј. проблем односа човека према Богу. Али, како је Августин схватио човека као личност?

Августин је личност човека поистоветио са инgивияуалном йрироgом у којој главну улогу има људски ум и разум (natura rationabilis individua supstantia). Оно што чини човеково „ја“, тј. личност, то је његов разум који руководи његовим индивидуалним животом (јер, управо под утицајем августиновског схватања личности, човек као личност се данас дефинише као самосвесна јединка, тј. неко постаје личност кроз логично одређење самог сеље и на основу логичног понашања у односу на свет око сеঠе). На овај начин, човек као личност постао је индивидуа која својим разумом урећује и контролише не само сеґе, већ захваљујући философским идејама каснијег периода, а посебно века просвећености, и све остало што постоји. Људска логика је постала једина водиља у животу човека у односу на њега самог и на остала бића и она је одређивала све: шта је добро, а шта зло, шта је последњи циљ човековог живота. Речју, људска логика је постала апсолутно доминирајућа над природом, тј. над постојањем.

Поистовећење личности човека са индивидуалном природом резултирало је поделом између човека као индивидуе и Бога, а у каснијој историји поделама између човека као индивидуе и природе, индивидуе и друштва, тј. заједнице, и на крају између индивидуе и друге индивидуе. Ове поделе имале су различите епилоге.

Подела између човека и Бога резултирала је тиме да човек у свом постојању није имао потребе за личном заједницом с Богом. По природи човек је био независан од Бога. Он је у свом постојању био независна индивидуа коју је Бог створио, али приликом стварања му је дао вечно биће и зато човек нема потребе за непрекидном заједницом с Богом да $\delta$ и постојао ${ }^{2}$. Човек, даље, постоји сам као индивидуа захваљујући својој природи. Једино што се тражило од човека, то је да испуњава Божије заповести на основу којих је био награђиван и био срећан или био кажњаван. Бог је гледао на човека и имао са њим однос у контексту испуњења или неиспуњења закона које му даје Бог. Будући да је људски разум поистовећен

2 На овоме се заснива касније настало учење римокатоличке теологије о „створеној благодати" (gratia creata). 
са иконом Божијом у човеку, људско делање у складу са разумом, са логиком, постало је израз Божијег деловања у свету. Као последица тога, сви Божији закони су потпали искључиво под власт људске логике и тако се духовни, тј. црквени живот, искључиво темељио на људској логици. У каснијем периоду људска логика је дефинитивно одређивала и то да ли Бог постоји и да ли је Он потребан човеку или не у његовом животу и у остварењу његових тежњи за блаженством, за вечним животом.

Подела између човека као индивидуе која се у животу искључиво руководи разумом, тј. логиком и природе довела је до схватања човека као субјекта, а природе као објекта којим руководи човек као субјекат. Наука се развила на основу логичког истраживања природе која је у односу на човека као субјект постала објект за истраживање и употребу. Техника је стварана на исти начин, а на основу ње долази до прогреса технологије која служи човеку ради искоришћавања природе. После наглог развоја науке и стварања технике, човек је мало по мало себе проглашавао за божанство док се коначно није устоличио као бог у природи изнад кога нема других богова, и од кога почиње апсолутно да зависи и само постојање природе. То човеково божанство у савременом свету апсолутно је зависило од технологије којом је он суверено завладао светом. Отуда ће технологија играти пресудну улогу у животу савремене цивилизације, тј. у обезбеђењу срећног живота за човека и од ње почиње да зависи постојање или непостојање не само природе, већ и човека.

Човек, као индивидуа која се искључиво руководи логиком у односу на друштво, на заједницу, јавља се као онај који логички уређује друштво, тј. друге индивидуе како би могли да се постигну одређени циљеви. Ово је довело до тога да се у постизању општег благостања и среће за човечанство користе крваве револуције, убијање свих оних који су стајали на путу остварења опште среће. На крају, то ће, по предвиђањима просветитеља и оних који логички посматрају и усмеравају живот, донети целом човечанству огромну корист. Та корист се може дефинисати као блаженство човека које ће као последњи циљ његовог живота бити остварено кроз развој науке и ненасилних револуција, као што је Енглеска индустријска револуција, али и насилних, крвавих револуција, ако је то потребно, као што су Француска, Руска, и друге комунистичке револуције. Речју, захтев човека као индивидуе за својом срећом коју је он дефинисао на основу своје логике довео је до ратова, крвавих и мирних револуција и државних преврата невиђених у ранијој људској историји, а који ће сви бити сасвим логички оправдани! Јер ништа није логичније у животу од тога да се оствари општа срећа за човечанство. Они који коче развој човечанства лоїички је да треба да буду склоњени са пута или милом, или силом. Но, то се у будућности неће више дешавати, тј. неће бити насиља ради остварења срећног живота за човечанство, говорили су просветитељи 
деветнаестог века? То се сада дешава због тога што су људи на ниском ступњу интелигенције, тј. нису образовани па сами не могу да виде да је то једино логично? Када сви прођу кроз школе и усвоје логички приступ животу, тада ће сви сложно да се повинују ономе што налаже логика и тако ће настати рај на земљи?

Касније, са прокламовањем индивидуалних слобода, „људских права“, друштво се организује у демократски систем, као скуп, односно колектив индивидуа којим руководи људска логика у постизању одређених циљева који сви, без изузетка, треба да служе човеку као јединки, али оној јединки која је логички и технолошки на неки начин супериорнија у односу на друге јединке. Тако је настало савремено демократско друштво у коме држава служи за остварење права јединке, човека као индивидуе, често са трагичним последицама за свет у целини.

Истовремено је човек као личност, такође захваљујући блаженом Августину, имао и своју сопствену подељеност у свом индивидуалном постојању. Са њим су постојале и две паралелне истине постојања: унутрашњи живот човека, тј. душевни и његова спољна делатност у односу на спољни свет и јавне институције. То човеково деловање и постојање се може другачије назвати и субјективно - приватно у односу на објективно и институционално - јавно и односило се на његов унутрашњи живот и његову спољну делатност. Унутрашњост човека, тј. његов душевни, психолошки свет је један огроман, необухватан свет, уз то још и мрачан и недефинисан као лавиринт, кога је Августин открио и изложио у својим

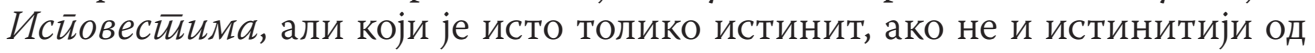
спољашњег. Тај психолошки свет човека као јединке је током историје савремене цивилизације често постајао образац за стварање спољног света паралелно са унутрашњим, али под будним надзором логике, који је често служио и као уточиште човековом бекству од реалности живота. На овај начин је настала могућност за двојни живот човеков у свим његовим сегментима: религијском, свакодневном, уметничком, научном, политичком и другим видовима живота. Те одвојене сфере живота ће се повремено сукобљавати, али и пружати уточиште у бекству човековом или од једне или од друге. То можемо именовати као постојање - субјекта и објекта код човека, односно - субјективизма и објективизма, који се испољава; на пољу вере, тј. религије као пијетизам или црквена дисциплина, милост, љубав или правда, вера као унутрашњи доживљај или знање, односно дела, теорија или пракса; на пољу уметности, као натурализам или романтизам; у друштвеном животу, као институција или револуција итд. На овим поделама, тј. на подели између личности као унутрашњег човека који је представљао човеков „его“ и његовог спољашњег израза, заснована је сва философија западноевропске мисли, и сви покрети како у друштву, тако и у уметности, књижевности и другде, који су се јављали у 
историји западне цивилизације и који се јављају и данас, почевши од рационализма, психологије, мистицизма, пијетизма, романтизма, па све до егзистенцијализма и нихилизма. Сви ови правци, међутим, апсолутно су били покретани на основу логичног схватања живота и контролисани су људском логиком.

Не укидајући оне особености које су карактерисале западну цивилизацију, а које смо већ именовали као организација и објективизација бића, човек је постао сам по себи апсолутно биће које организује свет по свом логичком нахођењу, како би он као организован могао да да резултате, тј. да буде користан. Под корисношћу се подразумевала срећа и блаженство за човека као индивидуу како у историјским, тако и у вечним, метафизичким оквирима. У ту организацију укључен је и други човек. Но, да би био погодан за организовање и да би та организација дала резултате, чо-

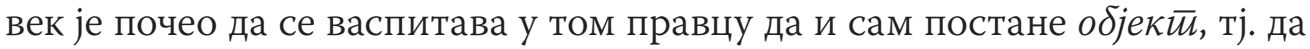
постане среgстиво у циљу остварења индивидуалне, или свеопште среће. Да би се то постигло, човек је морао да се одрекне свих осталих сила, воље, осећања, а посебно своје слободе, или, евентуално, да је ограничи, тј. да се потпуно потчини разуму, логици како би могао да постане погодан за организовање у циљу остварења опште и индивидуалне среће. То оспособљавање човека да се добровољно одрекне своје слободе ради постизања савршеног друштва спроводи се веома интензивно у средњем веку кроз схоластику, а у веку просвећености и на посебан начин. Тај посебан начин је оспособљавање човека да делује и живи логички кроз школе и школски систем образовања. У последње време човекову слободу је скоро апсолутно неутралисала технологија која му се наметнула као богиња од које зависи његово бити или не бити, пред којом човек дрхти, будући да је кроз логички приступ животу и захтевом за индивидуалном срећом човек доспео под апсолутну власт ствари и производа технологије. У оквиру логичког посматрања живота савремени човек се одрекао своје слободе ради „хлеба“, али и ради постизања виших циљева друштва: равноправности, једнакости и среће. Јер, одрећи се свега овог благостања ради слободе, апсолутно је нелогично, апсурдно и зато неприхватљиво за савременог човека!

Што се тиче последица које су настале на основу поистовећења човека са логичком индивидуом и његове одељености у односу на Бога, тј. на питање односа човека према Богу, које нас посебно интересује, на њега ћемо се вратити касније. Најпре да се осврнемо на последице које су настале на основу логичког приступа животу кога одређује људска индивидуа на пољу искоришћавања природе, а затим и на социјалном и антрополошком плану.

Због апсолутног контролисања природе на основу логике и њеног искоришћавања настао је еколошки проблем - проблем потенцијалног уништења природе, а самим тим и човековог самоуништења. Тежећи за 
својом индивидуалном срећом, на шта је упућивала логика и логично расуђивање о животу, човек се најпре јавља као опасност за постојање природе, а као последица тога и самог себе. У односу на природу јавља се као потрошач, посматрајући је као објекат и извор своје среће. У том циљу развија технику на основу логичног става према животу, тј. развија технологију којом мисли да може да учини од природе све што жели и тиме усрећи сеঠе. Дакле, логиком преточеном у технику, тј. технологијом, човек мисли да може решити све проблеме. Поред тога што је овај начин живота довео до еколошке кризе која у наше дане поприма размере светске катастрофе, као последице све већег уништавања природе ради остварења људске среће, технологија којом се то постиже постаје посебан проблем. Технологија је постала бог коме се клања читав свет јер она доноси срећу, уживање, али је она постала и монструм од кога све чешће свет дрхти. Кад технологија доспе у руке индивидуе, или организованих индивидуа какве су поједине савремене државе, које желе да себи осигурају срећу, онда она постаје средство којим се може уништити свет. Тачније, технологија постаје средство којим се полако али сигурно свет уништава, али, што је најпарадоксалније, вољом људи, тј. слободним пристанком тог истог света! Зठог тога што је и сама слобода човека потчињена логици и она може да делује само у складу са логиком.

Индивидуализам човека спојен са његовом основном карактеристиком, а то је логика, уздигао је човека не само изнад природе, већ и изнад другог човека. Човек као личност, посматран као индивидуа која у свом постојању не зависи нити од односа са другим, тј. од друге индивидуе, нити пак од постојања целокупне природе, угрожен је од стране друге индивидуе. Други човек, друга индивидуа стоји као препрека у остварењу потпуне среће за личност као индивидуу.

Једино из ове перспективе гледано, тј. схватањем човека као индивидуе која тежи остварењу своје среће, могу се објаснити све страхоте 20. века, холокаусти, истребљења, еколошки проблем, еутаназија, бела куга и друге, јер овај век је кулминација индивидуализма и логичности у животу човека као личности (Зизијулас, 2016).

\section{Однос савременог човека према Богу}

Под утицајем учења да је човек као личност индивидуа и логичног приступа животу унутар Цркве, на Западу су се појавиле најпре реформације, односно негирање Цркве и црквене јерархије као божанског ауторитета и јединог посредника између човека и Бога, а затим се појавио у савременом друштву атеизам и, на крају, сатанизам и нихилизам.

У контексту тога да је човек индивидуа у односу на Бога и да је његов ум и разум икона Божија у њему, тј. нешто божанско, што је резултирало тиме да је његов однос с Богом постао логички, тј. да се хришћански 
живот човека руководио искључиво логиком као Божанским законом, тј. моралним нормама, појавило се то да је тај однос постао јуридички, етички, тачније логички. Јер, човек као индивидуа је апсолутно одвојен од Бога. На то посебно указује поистовећење човека са његовом природом. Човек је природа, али за разлику од других животиња, он је мислећа природа. Као мислећа природа (natura rationabilis), како је човека назвао Боеције, у односу на Божанску природу (Natura Divinis), како је Августин и каснији западни мислиоци називао Бога, човек је био апсолутно индивидуалан, тј. неспојив са Богом. Веза између Бога и човека одржава се једино преко људског ума. Човек, као природа, постао је апсолутно одвојен од Бога, постао је само природа (човек) и ништа више. Све оно што је евентуално доприносило човековом достојанству као икони Божијој, заснивало се искључиво на његовој логици. Човек је постао само толико човек колико је могао да буде логичан у својим поступцима, јер је на тај начин био користан и доприносио је општој срећи и блаженству коју је, наравно, сам прописивао и дефинисао на основу свог разума а у складу са својим индивидуалним потребама. Руковођен тиме да је једино онај човек мерило истине уколико је логички, ментално здрав и испуњава постављене логичке циљеве, човек који то није могао да постигне постао је ништавно и трагично биће или, тачније, доведена је сама његова људскост у питање.

Будући да је човек као индивидуа онтолошки апсолутно одвојен од Бога, његов однос према Богу изражавао се испуњавањем Божанског закона, односно моралних норми. Бог и човек нису могли да имају никакву другу везу осим кроз закон, тј. кроз морал. Отуда врло рано на Западу лични однос човека с Богом замењује јуридички, законски.

Законски однос човека према Богу учинио је то да се Црква посматра као институција која једина чува Божанске законе. Црква је као институција постала чувар Божанских закона и њихов тумач кроз векове. Тим пре што се Божански закон, тј. морал, све чешће мењао. Божански закон схваћен као моралне, етичке норме, међутим, будући да је морао да прође људско тумачење, тј. људску логику, да би се тачно одредио и као такав испуњавао, неизоставно се претворио у логичке дефиниције и норме које су се временом мењале. И то у складу са захтевима човека као индивидуе. Речју, морални, Божански закон, претворио се у људски закон. Људска логика је постала мерило истинитости Божанских закона и темељ Цркве. На крају, Божански закон се потпуно поистоветио са логичким расуђивањем човека и као такав постао је служитељ потребама човека као индивидуе ради постизања срећног живота. Тако је настало то да се човек, уместо да се руководи у свом животу Божанском вољом, руководио својом вољом, наравно само уколико се његова воља уклапа у људску логику која у последњој инстанци осмишљава живот и прописује методе за његово остварење. Отуда је у веку просвећености било све сумњиво и одбачено, 
па чак и постојање Божије, ако се није уклапало у људску логику. Речју, савремено друштво, ту мислимо и на црквене људе, на први поглед као да се управља у свом животу Божанским законима, али, у суштини, то су закони створени на основу људске логике, тј. на основу природних закона и људска логика дефинитивно руководи људима и њиховим животима, али све, наравно, у име Бога.

Дакле, западни човек, схватајући себе као индивидуу која својом логиком управља својим животом, најпре је довео у питање постојање Цркве и њене јерархије као посредника између њега и Бога. Настале су реформације и протестантизам. Наиме, будући да се однос човека с Богом своди на испуњење Божанског закона, тј. моралних норми и начела, логички се поставило питање: зашто треба да постоје свете тајне у Цркви, њена јерархија, па, на крају, и сама Црква? Зар човек сам као индивидуа не може знати Божији закон и испуњавати га, тим пре што сваки човек има ум и разум којим и сазнаје све, па и Божански закон и оно што је добро и зло? Зашто му је потребна Црква као јерархијска заједница, тј. зашто му је потребан други човек у његовом односу према Богу? Дакле, као логичка последица индивидуализације човека у историји се појавио либерализам у моралу и протестантизам. Да би то спречила, Римокатоличка Црква је тврдила да је њено постојање потребно због тога што је она једини меродавни чувар и тумач Божанских закона. У истом циљу прогласила је римског папу за јединог непогрешивог тумача Божијег закона. Проглашењем римског папе непогрешивим, хтело се рећи да није сваки човек (као јединка) меродаван да тумачи Божију вољу и његов закон, већ само један човек, папа?! Међутим, чим је папа као јединка и његов ум меродаван тумач Божије воље, шта спречава да то не буде сваки човек, свака јединка? Јер, ако сваки човек има ум и разум, онда је сваки способан на основу разума да одређује шта је истина, а шта није.

Човек у одбрани од логичког уређења живота и односа према Богу претпоставља свој унутрашњи, психолошки доживљај као истински однос према Богу. То резултира појавом мистицизма на Западу. Речју, човек попут Паскала, посматра Бога на основу свога унутрашњег доживљаја који проглашава истинским духовним животом. У том контексту, међутим, није му потребан био други, нити Црква као јерархијска установа, осим као исповедаоница, тј. душебрижник који би га понекад избављао из душевног лавиринта у који је врло често западао. Отуда је главни акценат у црквама на Западу, поред проповеди, тј. школског, логичког убеђивања о присутности Бога и његове улоге у људском животу, стављен и на исповест која се темељи на унутрашњем, психолошком животу човека, а као нека врста логичке, институционалне контроле тог унутрашњег света човека. Речју, доживљај Бога се поистоветио са унутрашњим психолошким осећањем човека који је, будући да се често мењао, често и сам био сумњичав да ли 
се заиста ради о доживљају Бога или је посреди пуки природни доживљај, или болест, апсолутно морао бити под надзором и контролом логике ${ }^{3}$.

Савремена цивилизација је, поред тога што је ставила под сумњом само постојање Божије, ипак оставила могућност за Његово постојање, тј. да постоје они који и даље верују у постојање Бога, али опет под условом да је Бог поистовећен са природним и логичким начином живота, односно са унутрашњим осећањима која су такође плод природе, логике. У противном, то није прави Бог и није права вера?!

Као следећа етапа на Западу се појавио атеизам. Посматрајући живот логички, модерни човек као индивидуа искључио је из њега многе чиниоце, а пре свега Бога. Зашто?

Карактеристика логичног приступа животу јесте да се човек прилагођава природи и њеним законима. Јер, логика се темељи на природи и на њеним законима постојања и не може да превазиђе границе природе. Први плодови таквог логичног посматрања живота јесу нужност у постојању и поистовећење Бога са природом ${ }^{4}$, тј. мишљење да хришћански живот треба да буде у складу са природом. Зато ништа није логичније од тога да човек не чини ништа што је у супротности с логиком, с његовом природом, са његовим природним животом, а то је у исто време и живот по Божијој вољи 5

\section{Појава нихилизма, атеизма и сатанизма у савременом свету}

Оно што је занемарено, или, тачније, стављено у други план при одређењу човека као личности и његове улоге у савременој цивилизацији, поред других елемената, то је слобоga као кључни елеменат који и чини човека човеком. Тај елеменат, тј. слободу која треба да буде креатор живота, а не логика, истакли су покрети с почетка 19. века, тзв. модерни покрети; пре свега демократија на социјалном плану, егзистенцијализам у философији, а затим и у другим сферама људског живота, као што су сурреализам у уметности, нове појаве на пољу књижевности и другде, који су се појавили као директни противници логичком приступу и уређењу живота, стављајући у први план слободу човека као индивидуе. До каквих резултата су довели ови покрети?

3 Слично се данас гледа на исповест и у Православној Цркви.

4 Уп. Спинозу и његову философију. Отуда није случајно да је у веку рационализма основна брига теолога била да се на основу природе и природних закона потврди да Бог заиста постоји.

5 Отуда је у западном хришћанству морални закон, етика, који је назван Божанским, утемељен на природи и поистовећен је са природним законом, односно са логиком. На пример, брак између мушког и женског је божанска институција зато што је то природно, тј. логично. Пост је укинут на Западу, управо зато што се не слаже с природом, тј. нема логике у себи и зато он није божанска институција, итд. 
Будући да је човек поистовећен са индивидуом, његова тежња за апсолутном слободом неминовно је водила ка непријатељству према Богу, ка другом човеку и појави сатанизма, али и атеизма и, на крају, нихилизма. Сатанизам се појављује као борба против Бога, а будући да је Бог у савременом друштву поистовећен са природом, односно са логичким уређењем живота, он се испољава и као реакција на све оно што је складно и лепо, а што је утемељено на људској логици.

Атеизам и нихилизам који нас овде посебно интересује, јер се директно тичу питања које смо поставили у оквиру наше теме, односа савременог човека према Богу, важан је да се истражи као појава и за оне који се не баве проблемом вере у Бога, зато што оставља трагичне последице по живот уопште. Дакле, откуд нихилизам у савременој европској цивилизацији коју с правом можемо назвати хришћанском, тим пре што њега није било нити у латинској, нити у старојелинској философији, нити пак у хришћанској вери?

Нихилизам је директна последица схватања личности као индивидуе која одређује себе и своју срећу на основу логичног расуђивања о себи и о животу, али која је у исто време и слободна. Откривши слободу човекову као кључну на којој је савремена егзистенцијалистичка философија утемељила људску личност, а при том се апсолутно држећи Августиновог наследства да је личност индивидуа, иста ова философија је неминовно завршила са нихилизмом као логичким крајем човека. Одређујући себе као индивидуу на основу издвајања од других, човек све чешће долази у сукоб с другом личношћу. Јер ако једна индивидуа преовлада, онда она угрожава права друге. Непријатељ кога треба уништити огледа се у сваком ко жели да буде други у односу на мене, зато што угрожава својим постојањем моју апсолутну слободу. Други представља мој првородни грех, мој пакао, да се послужимо речима Ж. П. Сартра. Личност као индивидуа да би остварила себе у слободи неминовно негира другог. Из оваквог става као логични закључак појавио се атеизам, тј. негација Бога од стране човека. Јер Бог као други апсолутно угрожава човекову слободу. Да би човек био слободан, то изискује непостојање Бога.

Захтевање слободе за личност као индивидуу да би она била апсолутно слободна и срећна неминовно води у негацију Бога као другог, а у крајњој инстанци и у негацију самог себе, тј. у нихилизам. Јер, посматрајући свој живот, своју природу из перспективе да му је она дата од Бога као од другог, у захтеву да буде апсолутно, онтолошки слободан, човек мора да негира дато му биће, односно самог себе. Зато га остварење апсолутне слободе неминовно води у нихилизам, како је добро приметио Достојевски у својим делима ${ }^{6}$, и на тај начин се појавио као пророк онога што ће се неминовно десити са таквим светом у будућности. Наиме, ако човек као

6 Види Ф. М. Достојевски, Зли gуси. 
индивидуа жели да буде апсолутно слободан, он онда не само да треба да уништи друге индивидуе које му самим својим постојањем стоје на том путу ослобођења и среће, а у том контексту и Бога, већ треба да уништи и самога себе да би тиме показао своју апсолутну слободу, тј. да је он бог и да изван њега нема другог Бога.

Нихилизам неминовно повлачи за собом и атеизам. Јер, човек постоји на тај начин што му је природа, тј. само биће дато од другог (од Бога), који тиме негира његову слободу. Јер, биће које носимо дао нам је други, односно дао нам га је Бог, ма колико ми покушавали да прогласимо да је природа самопостојећа, самобитна и да није створена од Бога. Само постојање слободе личности налаже да се призна постојање другог (Бога), ма колико ми то избегавали и Њега мрзели. Зато не толико уништењем другог, колико самоуништењем човек постаје апсолутно слободан, како је приметио Достојевски7, јер једино на тај начин пројављује своју апсолутну слободу. Речју, себе проглашава за бога. Али та слобода, тј. то божанство је ништавило, небиће? Отуда је остварење човека као слободне личности у савременој европској цивилизацији апсолутно немогуће а да не заврши атеизмом и нихилизмом.

Из ове перспективе гледано може се објаснити и проглашење да је Бог мртав (Ф. Ниче), односно проглашење атеизма као јединог исправног става савременог човека према животу. Јер уздизање слободе личности која се схвата као индивидуа је нераскидиво повезано са негацијом Бога. Бог својим постојањем као апсолутно други у односу на човека угрожава лично, слободно постојање човека као индивидуе. Но, није довољно одрећи, или игнорисати Бога, да би притом човек био апсолутно слободан. На путу до те слободе човеку стоји други човек, зато овакво схватање личности човека има катастрофалне антрополошке последице које смо већ навели, али на том путу остварења апсолутне, онтолошке слободе за човека стоји само његово постојање које му је дато од другог и зато овакво схватање човека као индивидуе неминовно завршава у нихилизму.

Да би се ослободио смртоносног загрљаја са небићем човек савремене европске цивилизације у последње време напушта слободу, тачније ограничава слободу човека, очигледно свестан да ће га она одвести у ништавило, и као алтернативу поново предлаже логику, односно етику (Левинас) на којој заснива своју сигурност и свој идентитет. Не доводећи у питање индивидуалност човека, што је у суштини неспојиво са остварењем преображаја савременог друштва и бекства од ништавила, он само продужава агонију

7 „Ако Бога има, онда је све његова потпуна воља и ја не могу изван воље његове. Ако га нема, онда је потпуна воља моја и дужан сам да обзнаним своју вољу... Зато што је цела воља постала моја. Зар нико на читавој планети, кад сврши с Богом и увери се о својој вољи, неће смети без страха у главној тачки да покаже своју слободну вољу. Ја хоћу да обзнаним слободну вољу... Ја сам дужан да се убијем, јер најглавнија тачка моје слободне воље јесте: убити сам себе." Ф. М. Достојевски, наведено дело. 
човека. Предлажући закон, тј. етику на место другог човека као живе и конкретне личности која тежи апсолутној слободи, на основу које ће се регулисати односи у људском друштву и довести до блаженства за све, човек „постмодерне цивилизације“ предлаже бога као принцип, као идеју, али самим тим и човека, и тако чува своју индивидуалну сигурност, али при том укида човека као слободну, живу личност. То је нужно резултирало и свођењем човека од слободне личности на ствар, на идеју, на етички принцип. Идеалан човек је моралан човек, и то моралан на основу параметара које поставља људска логика у контексту организовања ради његове корисности, употребљивости, а не слободан човек. Уколико човек жели другачије да се понаша и живи ту су смртне казне и затвори који онима с друге стране дају сигурност и лажну мирноћу савести да су они добри, али, пре свега, они тиме чувају своју индивидуалност. Али то је исто и са схватањем Бога од стране савременог човека. Бог је Бог и постоји за модерног човека само уколико је користан, употребљив у контексту човекове логичне дефиниције шта је то добро, корисно, тј. употребљиво. Уколико се Бог не понаша тако, онда он за савременог човека и не постоји. Уместо Бога као слободне личности са којим да би остварио заједницу треба да жртвује свој индивидуализам, свој еіоизам, човек предлаже оно што још више утемељује и осигурава његов индивидуализам, а то је логика и самим тим не води ни у какав истински преображај и решење друштвених проблема.

За оваквом теологијом, односно за заменом живог Бога и човека етичким принципима посегле су данас, на жалост, и многе „цркве“. Међутим, ово алтернативно решење не води изласку из ћорсокака у који је запао човек савремене европске цивилизације, већ у још већу трагедију. Доношење закона за заштиту људских права, који су преточени у морал, као и заштиту животиња и природе да би се избегла еколошка катастрофа, и апеловање на људску логику да би се ти закони и морал поштовали како би опстали и људи и природа, представља гашење ватре сламом.

\section{Допринос Православне Цркве и њене теологије преображају савременог света}

Постоји ли алтернатива савременој цивилизацији, тј. оваквом начину живота и у чему је њена суштина? Шта би могло православље да допринесе у контексту промене света, тачније његовог избављења из ћорсокака у који је запао?

Најпре, једно упозорење свима онима који су позвани да данас представљају православље, пре свега теолозима и онима који су позвани да упознају савременог човека, а посебно децу у школама с њим. Православље није музејски експонат одређен да изазове дивљење код савременог човека у односу на оно што је оно било, или што је постигло у прошлости. 
Нити је оно одређено да буде средство за остварење националних интереса било које нације, или државе. Православље треба да буде спасење савременом човеку узимајући у обзир све ћорсокаке у које је он својом или туђом кривицом, свеједно је, запао. Ови проблеми савременог човека које смо укратко овде именовали, представљају изазов, али и оквир у коме треба Православна Црква да делује, чинећи истовремено предање отаца живим и спасоносним какво је оно вазда било. Речју, православна теологија треба да утемељи један другачији начин живота, да допринесе да свет поново постане Црква. Но, шта је то Црква, односно другачији начин живота у односу на савремени?

\section{Евхаристијски начин постојања човека}

Познато је да је еклисиологија (наука о Цркви) била тема 2о. века. То, међутим, још не значи да је овај проблем дефинисан и исцрпљен. Далеко смо још од тога. И то не само због тога што је суштина Цркве оно што ће она ठити, а не оно што она јесте сада, због чега је тешко дефинисати суштину Цркве, већ због тога што се еклисиологија више бавила оним што чини историју Цркве и етиком, а не оним што Црква јесте, тј. онтологијом Цркве ${ }^{8}$. Овде треба бити врло обазрив. Нису исто историја Цркве и етика и онтологија Цркве. Онтологија, за разлику од етике, претпоставља превазилажење проблема смрти, а не зла у етичком смислу. Људи могу бити савршени у свом моралном понашању, али ако умиру и ако не постоји могућност њиховог вечног постојања онаквих какви су, онда је сваки морал бесмислен. Хришћанство као Црква нуди управо решење проблема смрти, тј. спасење човека и природе тиме што ће они вечно постојати онакви какви су кроз васкрсење из мртвих, а не решење етичких, тј. моралних проблема. Свакако хришћанство говори и о укидању зла, али зла као смрти, као онтолошке категорије која се укида васкрсењем из мртвих, а не као моралне категорије. Уосталом, зло, ма како га дефинисали, постоји зато што постоји смрт. Црква је зато утемељена на онтолошким принципима, ако тако можемо да кажемо, а не на моралним, зато што је утемељена на васкрсењу и начину постојања који води у васкрсење и који ће владати после васкрсења. Историја, опет, бави се оним што се десило у прошлости, док онтологија говори о ономе шта је Црква и то у контексту ослобођења човека и природе од смрти. Црква спашава оним што она јесте (да се послужимо речима митрополита Јована Пергамског), а не оним што учи и што чини у моралном смислу. Црква је мерило и тврђава истине, тј. у односу на њу свет треба да оцењује да ли је нешто истинито или не. Кад кажемо, међутим, да је Црква истина, овде мислимо, пре свега, на истину

8 Ретки су теолози у савременој историји као нпр. о. Георгије Флоровски, митрополит пергамски Јован (Зизијулас) који су се ठавили теологијом Цркве, односно онтологијом (уп. Ziziulas, 2012). 


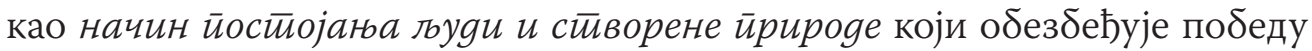
над смрћу и који се поистовећује са Црквом, а не, просто на њено учење, или на индивидуалну праксу људи утемељену на њеном учењу а усмерену на решавање социјалних, етичких или других проблема. Речју, Црква је нови начин постојања света откривен и понуђен њему као „лек против смрти“, да се сетимо речи Светог Игнатија Богоносца. У чему је суштина тог новог начина постојања човека? Пре него одговоримо на ово питање, желимо да укажемо на неке сегменте у животу Православне Цркве који отежавају правилно схватање суштине Цркве и њеног онтолошког значаја у животу човека.

Примећује се да савремене генерације православних верника ни мало, или врло мало знају шта је то Црква. Чак и не постоји велико интересовање верника за ову област. То значи да се постојање човека схвата као индивидуално и зато се хришћанство све више схвата као морални кодекс понашања човека као индивидуе, а све мање као Црква. Ово објашњава чињеницу да су многи људи верници, да верују у Бога, али нису црквени. Улога Цркве као да се свела на морални план, односно на социјалну делатност. Поред тога, православље се све чешће поистовећује са идеологијом, тј. са Божијим или моралним законима, а не са заједницом, Црквом, односно са Евхаристијом.

Црква се данас и на Истоку, под утицајем западног схоластицизма и праксе да се може бити верник без конкретне литургијске заједнице са другим човеком, односно мимо Цркве, само на основу моралног понашања, најчешће поистовећује и са институцијом и то моралном институцијом. Црква је, по мишљењу многих хришћана, божанска институција која чува моралне и Божије законе. Њу је основао Христос и предао јој учење и Божански закон који је најпре сам испунио, а затим то тражи и од осталих чланова. На основу испуњења или неиспуњења закона Христос ће нам на крају судити. Живот чланова Цркве је јуридичке, правне природе. Креће се у оквиру испуњења закона и казне и награде. Данас се под хришћанским животом све више подразумева морално или етичко понашање човека као јединке која испуњава Божанске законе. Службе у Цркви су чинови власти чији су носиоци људи као индивидуе, јединке и који свој ауторитет заснивају на моралу, тј. на испуњењу Божанског закона, или, боље рећи, који су добијени као награда за морални, врлински живот. Исти је случај и са Литургијом и причешћем. Литургија је схваћена као једна од седам светих тајни у којој се даје причешће као награда за врлински живот човека. Ради се, дакле, о моралном, јуридичком схватању Цркве која постаје колективна заједница људи, на основу њиховог индивидуалног испуњења Божијег закона у којој индивидуе за то добијају различите награде, а не као лична заједница људи, заједница с другим човеком на основу слободе и љубави, што је тада чини евхаристијском заједницом, заједницом служења 
једног човека другом. Црква је, дакле, под утицајем етичког виђења живота постала морална институција.

Овакво схватање Цркве је апсолутно обезвредило хришћанско откривење Бога као Свете Тројице. То да, пре свега, Бог постоји као заједница личности Оца и Сина и Светог Духа, као да нема никакву важност за живот човека. Друго, поистовећење хришћанског идентитета са моралним понашањем човека ставило је догађај оваплоћења Сина Божијег, његову смрт и васкрсење нас ради у други план. Догађаји, дакле, којима се Господ сјединио с нама до поистовећења и којима је и после свога вазнесења на небо остао са нама у литургијској форми „да нас преводи са земље на небо“, тачније, да се Духом Светим ми поистовећујемо с Њим кроз заједницу с другим човеком и да тако и ми постанемо синови Божији, постали су другостепени, док је у први план стављено Христово учење и његова безгрешност у моралном смислуя.

Да морал одређује истинитост хришћанског живота, као и то да се Црква данас поистовећује са моралном институцијом, а не са евхаристијском заједницом пресудно су утицале, по нашем мишљењу, између осталог, две ствари: схватање смрти као казне Божије за грех (учење блаженог Августина) и схватање постојања човека као индивидуе којој није неопходна заједница слободе и љубави са другим, тј. с Богом у Христу и с другим људима да би била личност и да би превазишла смрт. Кренуло се од греха као преступа моралних норми и смрти као казне Божије за преступ заповести, што је онда резултирало индивидуализмом и етиком. Јер, ако је грех преступ заповести и смрт казна Божија за преступ заповести, онда се превазилажење смрти налази у испуњењу божанских заповести, а светост као одлика вечног живота темељи се на моралном савршенству индивидуе.

Црква, међутим, као лек против смрти, нема много везе са моралом, иако то скандалозно звучи за оне који су је поистоветили са моралном институцијом. Она има везе са онтологијом, са начином постојања

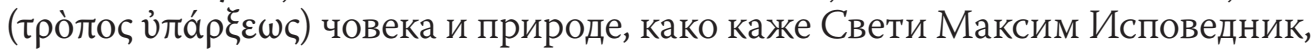

9 Ако бисмо и претпоставили да је морал мерило истинитости Цркве, морали бисмо и да констатујемо да је њена истинитост доведена у питање, јер очигледно је да често постоје моралнији људи изван Цркве, него у њој, као и то да морал сам по себи подлеже промени, зато што је утемељен на људској логици. Чак ако бисмо морал поистоветили са Божанским законима и тада би морал био потчињен људској логици и променљив, јер и Божански закони постају променљиви зато што потребују људско тумачење. Све ово доводи у сумњу истинитост Цркве и њен континуитет, уколико се она поистовети са моралном институцијом. Сведоци смо да се моралне категорије средњег века и ове данас битно разликују. И то не само у свету, већ и у Цркви. Та разлика сама по себи доводи у питање истинитост Цркве, односно њену непроменљивост. А ако Црква није истина, онда је доведено у питање и наше спасење у њој. Све оно што је засновано на моралним принципима данас се мења. Такав је случај данас са многим институцијама, па и са оним које себе називају Црквом. Многе цркве се управо због тога мењају и нису истинске цркве, зато што су утемељене на моралу, или ठоље рећи, на људској логици која одрећује морални живот, а која је сама по себи променљива. 
којим се превазилази смрт. Онтологија и морал су две различите ствари. Онтологија има за крајњи циљ укидање смрти и зато се она утемељује на Богу и васкрсењу из мртвих, док етика има за циљ укидање зла као моралне категорије, настале као преступ заповести и зато се она темељи на људској логици.

Откривење Божије у Исусу Христу донело је промену у односу на онтологију, а не у односу на морал. Та нова онтологија је Евхаристија, заједница Бога и створене природе у Христу, кроз слободну заједницу човека с другим људима. Шта то конкретно значи, шта је Евхаристија, тј. шта је Црква, будући да се Евхаристија и Црква поистовећују?

Да бисмо могли да разумемо Цркву као нови начин постојања природе, као и то зашто је она лек против смрти, потребно је најпре да се осврнемо на то шта је то истински начин постојања, тј. истински живот, а затим и на проблем смрти и откуд она у природи.

Кад говоримо о истинском животу то подразумева да говоримо о Богу и постојању Божијем. Јер Бог је једина истина и једини истински живот зато што је вечан, тј. ठесмртан.

На основу откривења Бога кроз Исуса Христа и у Христу као Свете Тројице, Оца, Сина и Светог Духа, као и на основу Тројичног богословља светих отаца, посебно кападокијских отаца, постојање Божије темељи се не на божанској природи по себи, већ на личности, на односу. Однос или зајеgничарење природе кроз личност је онтолошка категорија. Божија при-

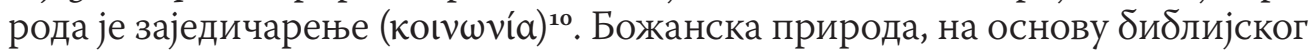
искуства, а затим и по учењу светих отаца никад не постоји гола, безлична, већ увек постоји као конкретна бића, као Бог Отац, Син и Свети Дух, тј. као личности, које постоје и јесу то што јесу на основу заједничарења једне с другом.

Постојање божанских личности, међутим, не извире из божанске природе, већ личности чине да постоји природа, тј. личност је извор постојања природе, а не обрнуто ${ }^{11}$. Када хришћани говоре о једном Богу, они под тим не подразумевају божанску природу, већ Бога Оца, не безличну божанску природу, већ једну конкретну личност. Један Бог Отац као конкретна личност подразумева, тачније претпоставља, постојање заједнице са другом личношћу, са Сином. Јер ако нема Сина, коме је Бог Отац? По речима Светог Григорија Богослова, постојање личности Оца, али и сваке личности у Светој Тројици, поистовећује се са о нносом, са заједничарењем са другом личношћу. На питање аријанаца: „Име Отац, шта означава, суштину или енергију“, одговара Свети Григорије: „Нити суштину, нити енергију, већ

10 В. Свети Василије, О Духу свет̄ом, 18 (PG 32, 194s). Упореди тумачење овог места код:

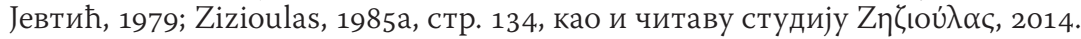

11 В. Зизијулас, 1995. 


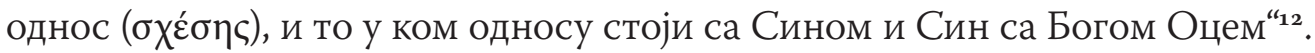
Ако је, дакле, Бог Отац конкретна личност, што је несумњиво за све свете оце, па и за Григорија, онда је Бог заједница, Света Тројица и постојање сваке личности у Светој Тројици је израз односа, заједнице са другом личношћу. Речју, ако Бог није Света Тројица, онда он није личност и не постоји.

Однос божанских личности је однос слобоge, љубави. Бог Отац слободно, из љубави рађа Сина и исходи Светог Духа. Постојање божанских личности је израз слободе Бога Оца који ту своју слободу изражава као љубав према Сину и Духу, односно тако што вечно рађа Сина и исходи Светог Духа. И Син и Дух вечно постоје у односу на Оца изражавајући тај однос као љубав према Оцу. Божанске личности постоје апсолутно слободно и јесу личности зато што своју слободу изражавају као љубав једне према другој.

Дакле, божанска природа постоји као заједничарење личности, а не сама по себи, нити, пак, као безлично заједничарење, односно заједничарење на основу нужности природе, већ на основу слободе. Бог је Отац, Син и Свети Дух, а не безлична божанска природа или сила.

Дакле, однос, заједничарење личности у Богу, јесте онтолошка категорија, али није однос нужности, већ слободе која се изражава као љубав једне личности према другој личности. Оно што произлази као закључак јесте да божанска природа не постоји сама по себи, већ као конкретна бића, као конкретне божанске личности: Отац, Син и Свети Дух који су то што јесу, тј. вечно постојеће личности, у оgносу слободе као љубави једне личности према другим.

Аналогно овоме, свети оци и постојање света, тј. створене природе виде у личности, у личности човека. Створена природа може да постоји једино у личности, као и божанска, никако као безлична. Зато је Бог на крају свега створио човека по „икони својој и подобију“, створио га је као биће заједнице, као личност и зато га је створио као Адама и Еву, и у њему, човеку, возглавио читаву творевину. Отуда Свето писмо кад говори о човеку, говори и у једнини и у множини (уп. 1Мој 1, 26-27), јер један, конкретан човек не може да постоји као личност без другог човека и заједнице с њим. Истовремено, Бог је створио човека као слободно биће како би и он могао да остварује заједницу с другим на основу слободе и да тако буде личност. По речима Светог Григорија Ниског: „Бог је слободно, самовласно биће и човек као икона Божија је слободно, самовласно биће“.

Бог Отац је створио свет ни из чега, што значи - прво, да свет пре него га је Бог створио није постојао и - друго да је немогуће да постоји сам за себе без заједнице с Богом. Овде укључујемо и човека јер је и човек од

12 В. Свети Григорије, Теолошка Secega 3, 16; уп. Свети Максим Исповедник, PG 91, 1265D. 
исте створене природе. На основу створености природе, свети оци доводе постојање света у везу са Богом као личношћу и његовом заједницом са човеком као личношћу. Јер, створена природа је, по речима Светог Атанасија Великог, некадашње небиће, и зато створена природа по себи не може да постоји. Њено постојање зависи не од ње саме, већ од односа с Богом зато што је Бог једини извор постојања. Дакле, да би постојао човек као личност и у њему свет, човек треба, поред заједнице с другим човеком, да има заједницу и с Богом.

Да би се остварила слободна заједница створене природе с Богом у којој би и створена природа постојала вечно, слично божанској природи, иако је створена, Бог је на крају створио човека као слободну личност, тј. као своју икону. Створио га је са циљем да у заједници слободе с човеком учини да и човек и његова природа, тј. сва природа у човеку, постоје вечно, као што и Бог као Света Тројица постоји. На тај начин хришћански оци и постојање света, тј. постојање створене природе поистовећују са односом, са заједничарењем човека с Богом. Однос слободе, љубави Бога и човека чини саму основу, ипостас постојања и створене природе. Из односа слободе, љубави Бога с човеком, произлази надилажење смрти за створену природу, односно њено постојање у личности човека који је то што јесте, личност, само у заједници слободе с Богом. Дакле, бесмртност природе се не темељи на природи по себи, већ природа и њено постојање, односно бесмртно постојање зависи од односа и то односа слободе, љубави човека с Богом. Речју, постојање природе зависи од личности у којој се налази и која је њен носилац, а то је човек и од његовог односа, тачније заједнице с Богом.

Из ове перспективе гледано, истински човек је биће које је у исто време у заједници слободе с Богом и у заједници с природом, а не индивидуа. Човек у себи садржи природу, тј. он је природа, док у заједници слободе с Богом јесте личност и на тај начин се човек јавља као спона између Бога и природе и носилац њеног постојања, односно као њена ипостас. Зато једино у човеку и кроз човека се пројављује Бог у природи, али и природа једино у човеку може да постоји вечно, јер је у њему и кроз њега у заједници с Богом.

Међутим, Бог није хтео да човек има заједницу с Њим на силу, без његове слободе. Јер то би значило да човек постоји на силу, што би као последицу имало уништење човека као личности и његово свођење на безличну природу. А то, практично, не може бити. Човек је човек само уколико има слободу и уколико ту слободу изражава као заједницу с Богом. У том циљу, Бог је на крају стварања створио човека слободним, тј. по лику и подобију свом, односно као биће заједнице.

Сагласно овом искуству живота, смрт гледана кроз искуство личности јесте смрт личности која настаје као последица ирекиgа зајеgнице 


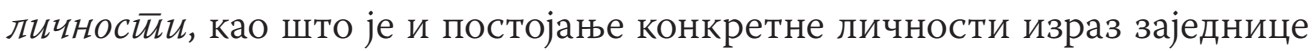
слободе, љубави с другом личношћу. Смрт природе једне личности почиње од момента кад се човек роди, или, тачније, од момента њеног стварања, како нам то тумаче свети оци Цркве ${ }^{13}$, али се коначно показује кроз личност као прекид личне заједнице с другом личношћу. Зато што природа не може никад да постоји безлично, већ само у личности и као личност. После смрти једне личности природа даје утисак да и даље постоји као безлична, али она опет постоји у конкретним личностима. Нови људи који се рађају су личности које носе исту ту природу која је постојала у личностима пре њих и зато деле исту судбину с њима, како у погледу живота тако и у погледу смрти. Смрт у нашем искуству не открива нам смрт природе, јер природа наставља да постоји и после смрти једне конкретне личности, макар и у другом облику, већ смрт личности као прекид заједнице умрлог са нама, мада она у крајњем случају настаје и као последица смртности природе. Зато, када посматрамо човека као конкретну личност, тј. као биће које волимо, он се апсолутно губи у процесу смрти који резултира коначним прекидом заједнице са другим личностима. Природа не може да надокнади једну умрлу личност кроз нове форме постојања, зато што личност није производ природе. Иако личност не може да постоји без природе, личност је носилац постојања природе, а не обрнуто.

Једино ако из ове перспективе посматрамо смрт, биће нам јасне Божије речиупућене првом човеку, Адаму, „у који час окусиш са дрвета познања добра и зла, умрећеш“ (уп. 1Мој 2, 17). Преступ заповести Божије од стране Адама био је прекид личне заједнице с Богом и зато је последица тога била смрт личности. Створена природа је и пре прекида заједнице била смртна, зато што је створена ни из чега, али будући да природа једино постоји у личности и њено постојање зависи од личности, она је могла да превазиђе то стање угрожености од смрти да је личност која је њен носилац остала у заједници с Богом. Исто тако, иако је изгледало да човек као личност и после прекида заједнице наставља да живи, он је живео као природа, а не као личност. Тачније, човек је давао утисак да живи на основу своје природе, а у ствари је природа у њему кренула ка небићу и у крајњем исходу би завршила у небићу да Бог није интервенисао. Природа није била бесмртна па је касније постала смртна. У личности Адама, да је он остао у заједници с Богом, природа би превазишла своју смртност и постала би бесмртна. Бесмртност створене природе захтева човека као личност и њену непрекидну заједницу слободе с Богом.

Источни оци Цркве, дакле, нису гледали на смрт као Божију казну за грех, нити, пак, на грех у етичком смислу као преступ заповести. Грех је прекид заједнице човека с Богом и као последица тога јесте смрт

13 До овог закључка је дошла данас и наука, констатујући да смрт природе настаје у моменту кад један организам достигне могућност да се размножава. 
личности, која у овом случају није могла да превазиће смрт која је садржана у створеној природи. То, међутим, никако не значи да је Бог створио смрт, будући да је створио природу. Природа је смртна због тога што је створена ни из чега ${ }^{\mathbf{1 4}}$. Но, природа никад не постоји гола, мимо личности и зато њено постојање, као и непостојање зависи од личности, а не од ње саме. Бог је дао могућност природи кроз човека, кога је даривао слободом, да превазиђе смртност природе постојећи, живећи на начин на који и Бог постоји, тј. у зајеgници слобоgе, љубави с Боіом, кроз коју би и gруї љууди и иела иррироgа били у зајеgничи с Боіом и живели би вечно. Први човек је, међутим, изабрао други начин постојања, прекинуо је заједницу с Богом, постао је индивидуа и утемељио је своје постојање и своју сигурност на себи и својој природи и промашио је, није остварио бесмртност. Зато је грех промашај (Свети Максим Исповедник) у онтолошком смислу и поистовећује се са смрћу, јер је прекид личне заједнице с Богом. Прекид заједнице с Богом је смрт личности која аутоматски има за последицу и смрт природе будући да је личност носилац постојања природе која је, опет, сама по себи смртна, јер је створена ни из чега.

\section{Стварање света кроз Сина Божијег и у Сину као човеку да би свет постојао вечно као Црква}

Пошто је неопходно ради нашег постојања, као и постојања читаве створене природе да имамо однос, заједницу с Богом, та заједница није могла да буде остварена ако прво Бог није открио себе и сишао међу нас, тј. ако прво Бог није остварио заједницу са створеном природом. То је потребно из два разлога - прво, само постојање створене природе подразумева заједницу с Богом. Друго, Бог је слободна личност и ако Он не би хтео заједницу са створеном природом, онда те заједнице не би ни било, односно створена природа не би ни постојала и самим тим не би могла сама својим силама да оствари заједницу с Богом. Другим речима, стварање света и остварење заједнице с њим је истовремено, јер да Бог није прво остварио заједницу слободе, љубави са створеном природом, односно с нама, ми не бисмо могли, нити да постојимо, нити пак да имамо заједницу с њим. Постојање створене природе истовремено подразумева и заједницу с Богом. Не може прво да постоји природа, па тек накнадно да остварује заједницу с Богом. У противном, то би значило да природа може постојати сама за себе без заједнице с Богом и да заједница с Богом није онтолошка категорија за створену природу. Овакво схватање се налази код многих теолога у њиховом тврћењу да је Бог, зато што је свемогућ, створио природу бесмртном по природи! У том случају, заиста однос, заједница створене природе с Богом да би природа постојала није ни потребна. Природа постоји на основу тога што је створена као бесмртна.

14 Види Свети Атанасије Велики, О овайлоћењу Сина Божијеї. 
Но, ако добро размислимо, то би значило да је Бог створио другог Бога поред себе, створеног, будући да је и Он као нестворен бесмртан. У том случају бисмо морали да говоримо о два бога: један нестворен, а други створен, што је апсолутни апсурд. Но, ако Бог није природи дао бесмртност усадивши ту бесмртност у саму природу, тако да створена природа буде ठесмртна по природи, на који начин се природа одражава у биће?

Већ смо рекли да то што чини природу постојећом јесте заједница, тј. личност и њена веза с Богом. Та личност која у самом почетку остварује везу између створене природе и Бога је, по учењу светих отаца, а посебно Светог Максима Исповедника, Логос Божији, Син Божији као личност. Пре стварања света је „одлучено“, по благовољењу Бога Оца, слободним пристанком Сина и садејством Светога Духа да личност која би била спона између Бога и створене природе и у којој (личности) би природа постојала вечно, иако је створена ни из чега, буде Син. На то упућује само стварање света описано у Светом писму, кад каже да је Бог све створио кроз Логос, тј. кроз Сина и у Сину посредством Светога Духа, будући да су свети оци поистовећивали Логос Божији са личношћу Сина. „Јер Њиме би саздано све, што је на небесима и што је на земљи: све је Њиме и за Њега саздано. И Он је пре свега, и све у Њему постоји“ (Кол 1, 16-17). По речима Светог

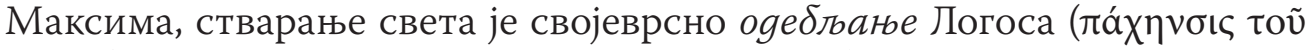
$\Lambda$ ó $о$ ov), или Његово оваплоћење. Како ово треба схватити?

Често се среће и у Светом писму и код светих отаца израз да то што чини везу између Бога и створене природе јесте љубав Божија према створеној природи, јер је Бог из љубави и љубављу створио све што је створио. Свети Максим љубав Божију према створеним бићима назива логосима твари

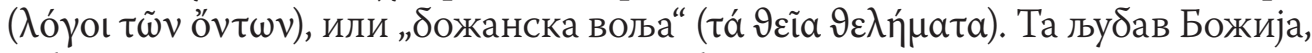
међутим, није психолошке природе, већ је личност и у личности Сина се пројављује. По речима Писма, „а ово је љубав Божија према нама да је Сина свога послао у свет да сваки који верује у њега не погине, него да има живот вечни“. Другим речима, однос Бога према свету који и држи створену природу у постојању спајајући је с Богом несливено и непроменљиво, али истовремено и нераздељиво, јесте његов Син као личност.

Истовремено, створивши природу ни из чега кроз свога Сина и у Сину, Бог се није претворио у своје дело, у створену природу. Божанска природа није исто што и створена природа. Тачније, Бог Логос је по својој божанској природи нестворен, неограничен, бесмртан, невидљив, неопипљив, несазнајан, необухватљив, док је створена природа у свему супротна нествореној. Својим енергијама које покрећу природу на кретање изван ње саме, тј. ка заједници с Богом Логосом, јер изван створене природе постоји једино Бог, створена природа указује на Бога као свога творца од кога она има своје постојање и указује својим кретањем на Бога као циљ свога вечног постојања и на тај начин и постоји ठез поистовећења с 
Богом по природи. Тај почетак постојања природе и њен крај је Бог Логос, тј. Син Божији у коме су садржане све енергије које су дароване створеној природи.

Ову исту стварност Свети Максим описује и на други начин. Кроз само стварање Логос Божији или Син се раздељује као „многи логоси“, многа божанска хтења која су присутна у бићима као њихова енергија. Стварање

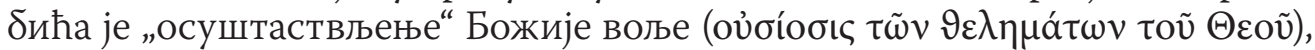
по речима Светог Максима. То се види из тога што сва створена бића теже да се сједине с Богом и да тако постоје вечно, налазећи у Богу испуњење своје тежње и крај, пуноћу, циљ свога кретања или енергије, дејства. Јер у сваком створеном ठићу видимо кретање изван њега самог, тј. видимо његову тежњу за бесмртношћу која се може достићи само у заједници с Богом као другим бићем које је изван природе, што указује да је та тежња од Бога, тј. то је божанска енергија у створеним бићима. Речју, један Бог Логос кроз стварање постаје многи логоси у многим створеним ठићима.

Божанска хтења, или енергије не постоје саме за себе безлично, у овом случају мимо личности Бога Логоса, тј. Сина, а аналогно томе ни створена бића у којима делује та божанска енергија не могу постојати мимо личности Логоса, тј. Сина Божијег. По речима Светог Максима, један Логос Божији постаје кроз стварање многи логоси, јер су то божанска хтења, енергије Бога Логоса у створеним ठићима, и многи логоси постају Један Логос кроз сједињење свих створених бића у Њему. То сједињење би требало да буде у личностии Бога Логоса кроз једну јединствену вољу и личност Бога Логоса. Један Бог Логос постаје многи логоси, и многи логоси су један Логос. Речју, у свим створеним ठићима, иако их има мно-

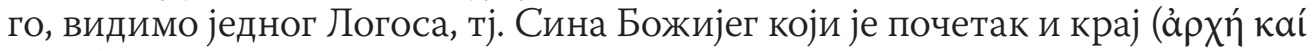

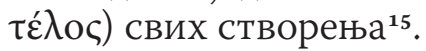

Будући, пак, да једино у заједници с Богом Логосом створена бића испуњују своју тежњу ка бесмртношћу, тј. ка постојању, кроз сједињење створених бића с Богом Логосом, а истовремено имајући у виду да је Бог Логос као Син Божији у вечној заједници с Богом Оцем, то сједињење створених ठића које остварује Син Божији, Логос окренуто је ка Богу Оцу. Другачије речено, та окренутост створених ठића ка Богу Оцу кроз началника Бога Логоса управо и показује да истинско сједињење створене природе с Богом и њено вечно постојање зависи од воље Бога Оца и да је једино могуће у и кроз Логос Божији, тј. кроз Христа.

Оно биће у природи кроз које се Логос Божији пројављује другачије него у свим осталим бићима јесте човек. Док сва створена бића имају

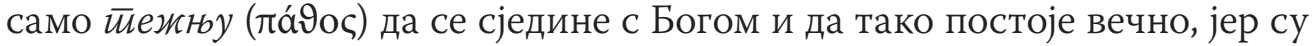
само природа, човек, поред те тежње по природи, будући да је и он део

15 УП. Свети Максим PG 91, 1081BC. 
целокупне створене природе, има и слобоgy, $\bar{u} j$. човек је сйворен као личносй. Човек, за разлику од осталих створених бића, може да бира да ли ће се сјединити с Богом, тј. да ли ће тежњу природе ка Богу управити ка сједињењу с Њим или неће. Речју, човек својом слободом руководи свим својим силама, па и тежњом коју његова природа као и све остале природе имају према Богу. И то због тога што Бог није хтео да створена природа постоји на силу, без њеног слободног пристанка. Ту слободу одлучивања о свом вечном постојању или непостојању Бог је природи дао кроз човека и у лицу човека. На овај начин човек и створена природа у њему створен је као икона Божија, сличан Богу. Та сличност се огледа управо у слободи и могућности да човек слободно одлучује о свом постојању као што то и Бог чини, јер Бог је апсолутно слободно биће и од његове слободе зависи и његово постојање. Бог слободно постоји, односно „хоће и постоји“, а не постоји по нужности природе или било чега другог. У противном, не би био Бог.

На овај начин створена природа самим својим постојањем показује да је у заједници с Богом, али и да може ту заједницу да прекине и да се врати у небиће, тј. да умре. Јер та заједница зависи колико од Бога, толико и од човека.

Будући да је Бог, стварајући човека на крају свега створеног, њега јединог створио слободним, тј. као икону Божију и њему наменио службу да се у њему и преко њега сва створена бића сједине с Богом, човек се јавља као икона Бога Логоса, тј. Сина Божијег, и то као личност а не по природи, од кога и зависи постојање природе. На овај начин долазимо до закључка да створена природа не може да постоји без човека и да је човек као личност онај који возглављује у себи целокупну природу одређујући јој начин постојања такав који значи заједницу с Богом, или прекид заједнице с Богом. Речју, човек као личност је начин постојања природе и тај начин је од Бога Логоса, уколико остане у заједници с Богом, те је тако човек његова икона и подобије, или је то прекид заједнице с Богом и постојање на основу природе. Шта то конкретно значи, тј. да је човек као личност икона Бога Логоса - Сина Божијег и да је позван да се уподоби Богу? Да бисмо одговорили на ово питање, морамо се подсетити на то шта је личност.

Син, као личност, значи однос слободне љубави према Оцу у односу на Кога је управо то што јесте, Син. Аналогно овоме, будући да је и човек створен слободним, тј. као икона Сина Божијег, и он је требало да буде у заједници с Богом. Његов однос према Богу је требало да буде однос слободе, љубави, онакав какав је однос Сина према Богу Оцу. Овакав однос учинио би да се човек у заједници слободе с Богом поистовети са Сином Божијим као личношћу. Попут оног поистовећења о коме говори апостол Павле речима: „А живим не више ја, него живи у мени Христос“ (Гал 2,20$)$. То поистовећење није имитација Христа, већ се остварује кроз 
слободни, „свесни излазак из себе“ и остварењем заједнице с Богом у Синовском односу, тј. на начин на који је ту заједницу касније остваривао сам Исус Христос с Оцем изразивши то речима: „не како ја желим, него воља Твоја нека буде“ (Мт 26, 39). Речју, човек је требало да има однос слободе, заједницу љубави с Богом како би се поистоветио са Сином као својим прототипом чија је икона био на почетку историје, како би створена природа у њему била ठесмртна. На овај начин би се испунила замисао Божија од пре стварања света у односу на сам свет, а то је да се све сједини с Њим у Сину његовом Христу, јер је Христос истовремено и Син Божији и човек, и да то сједињење буде слободно како од стране Бога, тако и од стране створене природе, тј. од човека и да тако створена природа постоји вечно. На овај начин би целокупна створена природа постала Црква као заједница многих у Сину Божијем који је у исто време и човек, тј. у коме је сва творевина Тело његово а Он личност тога тела, те би тако живела вечно иако је створена ни из чега.

Ово поистовећење човека са Сином Божијим по личности, кроз излазак из себе и остварење заједнице слободе с Богом, не треба схватити као губитак слободе и личности човека. Не ради се о губитку, како каже Свети Максим, већ о обожењу човека, тј. ради се о „антрополошком максимализму“ јер човек постаје Бог, тј. Син Божији по благодати, иако не по природи, не престајући да буде човек по природи. Осврћући се управо на овај проблем, Свети Максим пише: „Нека вас не збуњује ово што сам рекао. Није реч о одрицању од слободе, тј. од постојања личности (тог̃

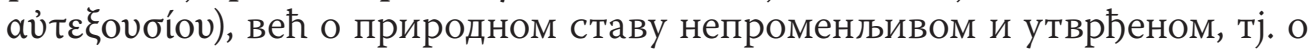

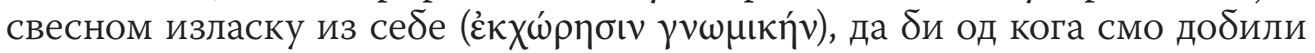
биће ка томе ठило и наше кретање, како би икона узашла до свог прототипа и као исправан печат са прецизношћу се поистоветила са прототипом, тачније, како би обожењем постали бог... И то на тај начин што смо благодаћу Духа досегли томе чему смо тежили, показујући да смо у себи имали самога Бога који је ово чинио, тако да у свему постоји само једна јединствена Божија енергија и оних који су достојни Бога, или, тачније,

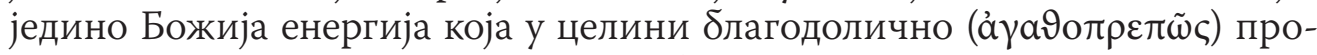
жима све оне који су се удостојили обожења" ${ }^{\text {"16 }}$.

Стварање првог човека, Адама, по Божијем лику и подобију јесте, ако изузмемо само стварање природе као откривање Божије које је остварено такође кроз Сина, тј. кроз Логос, прво истинско, иако делимично, његово откривање, тј. овайлоћене Лоїса. На овај начин Бог се први открио свету преко свога Сина кроз човека и у човеку Адаму, иако то откривење није било у потпуности, већ као икона. Лик Божији у човеку, по тумачењу светих отаца, јесте слобоgа. Будући да је човек једино слободно биће у створеној природи, једино је човек икона Божија, односно он је тај кроз кога се Бог

16 Свети Максим Исповедник, PG 91, 1076vs. 
пројављује у природи. Бог је, дакле, себе открио природи, тј. открио се у природи кроз човека и као човек кроз слободу коју му је даровао.

Да би се човек Адам потпуно уподобио Сину, тј. своме прототипу чија је икона, потребно је било да и он то слободно жели ${ }^{17}$. Речју, даровану му слободу човек је требало да пројави тако што би прихватио заједницу с Богом. По речима Светог Иринеја Лионског, човек је створен као мало дете са циљем да напредује у слободи и достигне меру обожења. На тај начин би човек постао подобан Богу, тј. Сину Божијем, када би своју слободу у односу на Бога пројављивао тако како Син пројављује своју слободу према Оцу, а то је љубав према Оцу.

То би се остварило кроз човеково одрицање од своје воље и кроз испуњење воље Божије. Кроз одрицање од свога „Ја“ које извире из његове природе, тачније које се темељи на његовој природи, први човек Адам $\delta и$ се потпуно сјединио са Сином Божијим до поистовећења. Јер би у том случају његово „Ја“ извирало, темељило се на заједници слободе с Богом. Постао би савршени Син Божији као личност, док би по природи остао створен, тј. човек, али савршени човек. Јер, идентитет једне личности, тј. постојање личности, зависи од тога како употребљавамо слободу, односно с ким ступамо у заједницу. А на основу тога и природа постоји или не постоји, јер њено постојање зависи од личности. Јер, као што смо већ раније изнели, личност је однос, однос слободе с другом личношћу. У том контексту Син Божији је личност, тј. Син у односу, у заједници слободе с Богом Оцем. И као што Син носи у себи Оца, јер каже: „ко види мене види Оца... Речи које вам ја говорим не говорим од самога себе, него Отац који пребива у мени он твори дела... и Ја сам у Оцу и Отац у мени“ (Јн 14, 9 и даље), не престајући да је Син и конкретна личност, тако би и човек у заједници са Богом пројављивао Бога, тачније, постао би Син Божији, не престајући да буде конкретан човек.

Да би се остварило оно што се касније остварило у Христу и његовој Цркви, а то је јединство свих створених бића у Богу Логосу а преко њега јединство с Оцем, Бог је изабрао на почетку историје једног човека, Адама, који ће се слободом као љубављу према Богу поистоветити с Богом Логосом, тј. са Сином Божијим као личност, и тако сјединити сва створења у себи с Богом.

17 Икона се тумачила тако што је она чинила присутним прототип који је иконизовала. Овај закључак се може извести на основу тога што су свети оци називали Христа, Сина Божијег, иконом Оца, по речима Светог Атанасија: „Син Божији је икона и истина Оца“. Син Божији је у овом контексту икона и истина Оца зато што је у вечној заједници слободе, љубави са Оцем, ঠез кога ни Отац није Отац. Када говоримо о човеку као икони Божијој, онда мислимо на однос слободе, љубави, који човек има с Богом и на тај начин чини присутним Бога као прототип у створеној природи. Та присутност прототипа кроз икону није у њеној природи, већ кроз однос који је имала са прототипом. Свети Теодор Студит каже да икона показује прототип по ипостаси, тј. кроз личност, а не по природи и преко природе. 
Да би ово постигао, први човек, Адам, требало је да крене од своје врсте, тј. сједињујући најпре другог човека, Еву, са собом. Својим односом према жени Еви као према другом човеку, и то односом слободе, заједницом слободе, а не заједницом по природи, први човек, Адам, показао би својом слободом да жели заједницу с Богом. Зато што се Бог пројављује у створеној природи једино кроз човека, и то кроз сваког човека, јер су сви људи иконе Божије, тј. слободни су. У тој заједници слободе с другим човеком и с Богом и човек Адам би постао личност, тј. подобан Богу. Јер личност постоји само у заједници слободе с другом личношћу.

Сједињујући друге људе и остала бића у себи а кроз своју везаност за Бога, први човек би у себи, у својој личности објединио целокупну природу у једно, тачније у једном (у себи као личности), која је приликом стварања ठила разједињена временски и просторно, а кроз своје сједињење с Богом цела природа би се нашла у заједници с Богом и постала би бесмртна.

Јединство, пак, са осталим бићима која нису имала слободу било је потребно ради превазилажења смрти, тј. због тога што је раздељеност природе међу собом приликом стварања носила у себи смрт. Јер су бића, тиме што су створена, настајала у различита времена и била су подељена међу собом не само просторно, него и временски. Надилажење смрти за створену природу подразумевало је јединство бића мећу собом, али да то јединство не доведе до сливања по природи, јер би се на тај начин бића уништила, а не спасла од смрти. Да би се то остварило, потребно је било да једно биће буде прво међу бићима око кога би се ујединила остала бића и да буде слободно, да би то јединство било нераздељиво, али и несливено. И то је био човек и његова служба: да сједини сва бића у себи не сливајући се са њима, и да их сједини с Богом. Зато је био потребан подвиг од стране човека. Тачније, подвиг је подразумевао да човек све више усваја понуђену му заједницу од стране Бога који је први ту заједницу с човеком и почео кроз љубав према другом човеку и природи, које би кроз своју везаност за Бога приводио и сједињавао с Богом.

Речју, цела природа и сви људи би, такође, ступили у заједницу с Богом, али кроз човека Адама који би се својом заједницом, јединством са Богом поистоветио као личност, а не по природи са Логосом и тако би на крају многи постали један Логос Божији - Христос.

Говорећи о заједници човека, најпре са створеним бићима, Свети Максим Исповедник каже да је човек требало да почне најпре са остварењем заједнице између мушког и женског, али не по природи, полно, већ на основу љубави као слободе, тј. онако како се та заједница остварује у Литургији, у Христу, а затим и са свим осталим бићима. Тако би се на 
крају остварило јединство читаве природе међу собом и са Богом у Сину Божијем као Адаму․

Остварење овог циља, као што смо већ напоменули, захтевало је од првог човека, Адама, подвиг, у том смислу да оствари заједницу слободе, љубави с другим човеком, с природом и с Богом. Будући да се Бог пројављивао кроз човека, кроз његову слободу, остварење заједнице љубави с другим човеком и природом показало би саму Божију љубав према створењима. С друге стране, остварењем заједнице Адама с другим човеком и са осталим створеним бићима, али пре свега с другим човеком, човек Адам би пројављивао да је икона Божија и да је личност, јер је човек као личност икона Бога, и то само кад је у заједници слободе с другом личношћу. Истовремено, будући да ни Адам нити други људи, у овом случају Ева, нису били богови, већ само иконе Божије, њихова међусобна заједница је требало да се возглављује у Богу, тј. изван њих самих. Јер, само у односу на истинитог Бога, а не у односу на икону Божију, могао је човек Адам и остала бића да се обоже, тј. да постану бесмртни. У том циљу Адам је као човек био тај који је постављен од Бога да буде началник и ујединитељ све твари с Богом, али истовремено да буде и у јединству са осталим људима и створеном природом. Разликовање Адамово у односу на друге људе, који су такође иконе Бога јер су слободни, извирало је управо из места које је он заузимао између других људи, пошто је Адам био йрви, тј. постављен од стране Бога за началника целокупне твари, као и из његовог односа који је требало да има с Богом Оцем. На овај начин Адам, као началник све твари, постао би Син Божији, Христос. Зато што личност Сина Божијег извире, пре свега, из заједнице са Богом Оцем, али је Христос истовремено и у заједници са целокупном творевином.

Кроз заједницу слободе са осталом природом и с Богом Оцем први човек, Адам, постао би бесмртан по природи и конкретна личност, тј. уподобио би се Сину Божијем, Христу. На овај начин човек би пројавио да је по лику и подобију Сина Божијег. Другим речима, створена природа би постала Црква, заједница свих створених бића у човеку Адаму, а човек Адам би постао син Божији по благодати, тј. Христос, и у њему и кроз њега и остали људи би постали синови Божији. Јер, управо ово изражава Црква као литургијска заједница. Тако би се испунио првобитни план Божији о створењима, да сва буду сједињена у Богу Логосу, а преко њега са Оцем.

Овај план Божији нам открива да би сва створена бића постојала као Литургија и у Литургији, тј. као Црква коју пројављује Литургија. Но, о овоме ће бити речи касније.

На овај начин Бог је дао могућност природи да постане бесмртна кроз човека, а човеку да истовремено постане бесмртан, јер је човек од исте те

18 Уп. PG 91, 1304D-1308C. 
природе, и да постане личност, сличан Богу. Јер, као што смо већ рекли, личност извире из заједнице слободе као љубави према другој личности. Слобода Божија се у Његовом вечном постојању изражава као љубав Оца према Сину и Светом Духу и обрнуто. То, на крају, и чини Бога Тројицом, односно Оца, Сина и Светог Духа вечним и различитим личностима.

Човек је, међутим, остварио заједницу са природом уместо с Богом, остварујући заједницу с другим човеком по природи, а не на основу слободе. Човек се на овај начин слио с природом. Да би осигурао своје постојање, први човек, Адам, окренуо се природним односима и увео природне, биолошке односе у створену природу на којима је засновао своју сигурност постојања. Међутим, човек као личност, као биће заједнице коју остварује на основу своје слободе, остварујући природну заједницу са створеним бићима, престаје да има заједницу с Богом и на тај начин (п)остаје смртно биће. Зато што се човек као икона Божија пројављује у створеној природи само у односу слободе с другим човеком и са осталом природом и са Богом, а не у природном односу, тј. не у односу по природи. Тако, уместо да достигне бесмртност у личној, слободној заједници с Богом и кроз заједницу слободе с другим човеком и природом, и да у тој заједници постане непоновљива личност, Син Божији по благодати, први човек, Адам, је кроз природно сједињење и размножавање (п)остао смртан. У томе је суштина пада првог човека: хтео је да кроз биолошко сједињење с другим човеком и размножавање достигне бесмртност за себе као личност, али је промашио, погрешио је. По речима Светог Максима, праоцу Адаму је била дата власт над природом, тј. над телом у том смислу да воли ближњега као самог себе, али не по телу и као тело, већ као личност, и да на тај начин достигне обожење кроз заједницу са Творцем, а не са творевином. Међутим, он је то злоупотребио и учинио је управо оно што му је било забрањено, тј. сјединио се са телом и постао је смртан. „То је, дакле, човек и ради овога је створен, међутим, праотац је употребио власт која му је дата над природом на зло, преусмеравајући своју вољу од онога што му је дозвољено, на оно што му је било забрањено. А био је слободан или да се сједини с Господом и да постане један дух с Њим, или да се сједини са женом телесно и да постану једно тело. Преварен, добровољно се удаљио од божанског блаженог циља и уместо да постане бог по благодати, постао је по своме избору земља“"

\section{Оваплоћење Сина Божијег}

Да би спасао природу од пропадљивости после пада Адамовог, Бог је на неки начин требало поново да успостави заједницу са створеним светом, а да то буде истовремено откривење Божије, тј. да иницијатива успостављања те заједнице буде у Богу и да то откривење буде кроз човека и у човеку.

19 Свети Максим Исповедник, PG 91, 1092A-D. 
Јер, мимо заједнице природе с Богом не можемо говорити о постојању природе. Та заједница, међутим, није могла да се оствари ако то Бог не учини први. Човек не може да се сједини с Богом ако прво Бог не сиђе и сједини се с природом. А ако постоји заједница Бога с природом, онда имамо постојање човека као личности, као иконе Божије, слично првом човеку, Адаму. Речју, требало је да се јави нови човек, нови Адам, који би био носилац постојања природе, али који би био истовремено и у заједници с Богом. Тај нови човек би требало да буде у заједници слободе с Богом и истовремено са створеном природом, као што је то био Адам на почетку историје. Рађање такве личности је имало исти циљ као и стварање првог човека, Адама: да се оствари заједница Бога и створеног света, али опет кроз човека и у човеку, а ради вечног постојања створене природе. После пада првог човека постојале су две могућности: или да Бог створи нови свет и новог човека препуштајући палог човека његовој трагичној судбини, или да спашава постојећег палог човека постајући сам човек, тј. да Бог постане човек. Јер нико од људи рођених на природан начин, поготово после греха, тј. прекида заједнице с Богом, није могао да буде спаситељ створеног света, зато што самим својим рођењем није у заједници с Богом. Само биолошко зачеће човека подразумева прекид личне заједнице људи с Богом и остварење заједнице са створеном природом ${ }^{20}$. Истовремено, и онај који се рађа на овај начин такође није у заједници с Богом ${ }^{21}$. А ако нису у заједници с Богом приликом самог рођења, онда су смртни. А ако су смртни, онда заједница с Богом коју би касније евентуално остварили није онтолошка заједница. Зато, сви који се рађају на природни начин јесу смртни од самог свог рођења. Зато нико од људи рођених на биолошки начин није могао да буде спаситељ створене природе од смрти. Зато што је биолошко рођење човека аутоматски ограничење рођеног на биолошки, природни начин постојања, који је затворен сам у сеঠе, ठез заједнице с Богом, и зато се биолошки начин рађања и постојања поистовећује са смрћу.

Требало је, дакле, да спаситељ света, као личност, најпре буде у заједници с Богом, да би могао да буде спаситељ природе, али истовремено је требало да буде, да постане и човек, тј. да укључи у своју личност и створену природу. Другачије речено, да би се природа спасла од смрти требало је поново да ступи у заједницу с Богом у једној личности и кроз личност, која је већ у заједници с Богом од самог свог зачећа и рођења као човек. И није могло бити другачије, него да Бог постане човек, тј. да се Син Божији оваплоти. Јер, једине личности које имају вечну заједницу с Богом су Син Божији и Свети Дух. Син Божији је по благовољењу Оца и садејством

20 Због тога су поједини свети оци, као што су Григорије Ниски, Максим Исповедник и други, сексуалне односе поистоветили са грехом.

21 Речи псалмопевца Давида, „у гресима се зачех и у безакоњу ме роди мати моја“, показују да је онај који се рађа на природни начин плод греха, и грешан је зато што није у онтолошкој заједници с Богом. 
Светог Духа преузео слободно да он буде тај који ће се оваплотити да би поново довео створену природу у заједницу с Богом. Ово нас упућује на овайлоћене Сина Божијей, на оно што је и на самом почетку стварања био план Божији, а то је да се све сједини у Богу Логосу, али саgа на gруіачији начин него што је то било на почетку историје приликом стварања првог човека. Циљ је остао исти као и на почетку, а то је сједињење створене природе у Богу Логосу, али је сада начин остварења тог циља промењен. Самим стварањем од Бога као слободне личности, први човек би кроз љубав према Богу остварио заједницу с Богом и узрастањем у тој заједници поистоветио би се са Сином Божијим као личност. То поистовећење првог човека са Сином Божијим по благодати зависило је и од човекове слободе, и зато је могло и да се не оствари, као што се није ни остварило у првом Адаму и зато је он био само икона Божија. Христос, као нови Адам, самим својим рођењем као човек био је већ у заједници с Богом, али у пуноћи, зато што је он и као новорођени човек Син Божији, а не само као икона ${ }^{22}$, премда је Христос као човек прошао све фазе живота од детињства до зрелог доба. Но, Христос је и као дете изражавао своју слободу као везаност за Бога Оца (уп. Лк 2, 49).

Син Божији, Христос, требало је да се роди као човек, али не на природни начин како се рађају сви остали људи. Јер, природно рођење би имало за последицу то да ठи Христос од самог свог зачећа као човек био роб смрти и не би могао да буде спаситељ. С друге стране, Син Божији је требало да постане човек, тј. да узме у своју личност људску природу и то није могло да се оствари ठез рађања од матере. Јер, овај вид доласка човека на свет, тј. у живот, увео је први човек после пада. Зато је Син Божији рођен од мајке Богородице, али не на природни начин, већ од Духа Светог и Марије Дјеве, тј. од девојке ठез учешћа мужа.

Христос самим својим рађањем као човек од Духа Светог и Марије Дјеве доноси у себи, у својој личности заједницу Бога са створеном природом, и зато је он једини спаситељ света. Јер је он као Син Божији вечна личност, тј. у вечној је заједници с Богом Оцем, и у ту заједницу је увео својим рођењем као човек и створену природу и учинио је од самог свог зачећа бесмртном.

Говорећи о оваплоћењу Сина Божијег, Свети Максим Исповедник говори да је логос природе, тј. циљ због кога је она створена остао исти, промењен је начин (тро́тоৎ) постојања природе и остварења тог циља, тј. промењен је начин сједињења личности Сина Божијег као носиоца њеног вечног постојања и човека, тј. створене природе. Уместо старог Адама,

2 Та пуноћа јединства тварног света с Богом у Христу, која је имала као последицу бесмртност Христа као човека изражава се тиме што се за Христа каже, да је он све што је учинио а што изражава његову трулежност, па на крају и само његово умирање, израз његове воље а не нужности, као што је то случај код свих осталих људи и бића. Христос је хтео слободно да пати, да гладује, да жедни и да умре и то из љубави према нама, а да то није морао. 
Нови Адам, Исус Христос, уместо природног сједињења Бога Логоса с човеком Адамом, натприродно рођење од Духа Светог и Марије Дјеве. То значи да је опет Син Божији као човек то биће, тј. та личност која је спона између Бога и створене природе, али се то сједињење сада догодило на други начин. „Човек је добровољно заменио овај начин погрешном употребом физичких сила и да се не би (човек) апсолутно удаљио од Бога поставши стран Богу, уведен је други начин - парадоксалнији од претходног и богодоличнији, колико је узвишеније оно што је натприродно од природног (...) Јасно је, дакле, свима, да је тајна која се збила у Христу на крају века несумњиво потврда и испуњење онога што је у почетку времена промашено у праоцу“, каже Свети Максим²3.

Син Божији је постао човек и оваплотио се не као божанска природа, тј. не по природи, већ као личност узевши у себе, у своју личност, људску природу, а преко ње и осталу створену природу и на тај начин постао човек, Исус Христос. Јер, шта је личност, односно човек ако не слобода која се изражава као љубав према другој личности, тј. према Богу као личности од које личност и добија свој непоновљиви идентитет, будући да личност чини природу коју носи постојећом и људском? Христос је као личност Син Божији зато што је у вечној заједници слободе, љубави с Богом Оцем и ту заједницу је донео и нама. Узевши створену, људску природу у своју личност приликом оваплоћења, тј. поставши човек, Христос је њу као своје тело довео у везу слободе, љубави с Богом Оцем и тиме је учинио бесмртном. Речју, својим оваплоћењем Син Божији је поново успоставио однос између створеног света и Бога Оца и постао је Нови Agaм и Начелник целокуйне йворевине и дао је могућност свим људима да и они постану део тог односа, тј. да се сједине с Њим и gа йостиану Тело Хрисйово и да на тај начин постану синови Божији. На који начин остали људи и природа могу постати део тог односа који је Христос својим оваплоћењем донео, тј. остварио и понудио га и нама као лек против смрти? Одговор на ово питање нам открива онтолошку улогу Свете Евхаристије као заједнице Тела Христовог, односно Цркве, и њеног постојања за живот света. Но, пре него почнемо са анализом литургијске заједнице као онтолошке за свакога од нас, потребно је да се осврнемо на само рођење Господа Исуса Христа и на то како се оно догодило, као и на смрт Господа нашег Исуса Христа нас ради. А то нам је потребно да бисмо разумели наше ново рођење које је предуслов за учлањење у Литургију у којој и ми постајемо судеоници вечног живота у Христу.

Исус Христос, Син Божији, рођен је као човек оg Духа Свейої и Марије Дјеве. Није се родио од мужа и од жене како се сви људи рађају, већ од Марије Дјеве без учешћа мужа, посредством Светог Духа. У чему је суштина

${ }_{23}$ Уп. Свети Максим Исповедник, PG 91, 1097BCD. 
делатности и посредовања које остварује Свети Дух у догађају оваплоћења Сина Божијег?

Дух Свети својим деловањем остварује заједницу Бога и човека. Где је Дух тамо је заједница. По речима апостола Павла, „заједница Светога Духа да буде са свима вама“. Друго, заједница Бога с човеком и природом треба да буде заједница слобоge, а не нужности управо ради превазилажења смрти створене природе. Без јединства са Богом створена природа не може да постоји. Истовремено, то јединство треба да буде слободно, како од стране Бога, тако и од стране човека. Јер свако јединство тварног са нетварним по природи, насилно, без слободе, довело би до уништења тварног. Зато је Бог на почетку историје оставио Адаму слободу да и он слободно пристане на заједницу с Богом коју му је прво Бог понудио. Ту слободу заједништва такође остварује Дух Свети. Јер, где је Дух тамо је слобода, по речима Светог писма.

Дакле, јединство Бога и творевине у Христу Богочовеку које остварује Дух Свети, делујући како од стране Бога, у силаску Сина у свет, тако и од стране човека, у прихватању тога силаска од стране Богородице Дјеве, јесте јединство у слободи. Речју, јединство створеног света преко човека с Богом у личности Исуса Христа остварује Свети Дух и зато је то јединство у слобоgu.

Оваплоћењем Сина, заједница створене природе с Богом Оцем у личности Сина Божијег, Христа, остварена је на исти, слободан начин, како је требало да буде остварена на почетку историје, а није због одбијања првог човека, Адама. Ту слободу је показала Марија Дјева (в. Лк 1, 38). Јединство створене природе с Богом у Христу слободним пристанком како Бога, тако и човека - Марије Дјеве, чини природу бесмртном, не мењајући првобитни план Божији о свету, али мењајући начин остварења тог плана: уместо Адама Исус Христос, и уместо сједињења Адама с Богом Логосом кроз одрицање од своје воље, натприродно рођење самог Бога Логоса, Сина Божијег као човека од Духа Светог и Марије Дјеве.

Дакле, идентично као што је то требало да се оствари и у првом човеку, Адаму, тј. слободним пристанком како Бога, тако и човека.

Иницијатива ради остварења овог чина била је у Богу. Прво је Син Божији, и то слободно, пристао да се оваплоти. И ово је, дакле, исто као и на почетку историје. Слободни пристанак ради сједињења с Богом створена природа је дала и у личности Марије Дјеве као човека. То што је требало да се догоди на почетку историје, а није се догодило због одбијања првог човека, Адама, догодило се сада, у рођењу Христа.

Ову слободу у сједињењу Бога Логоса и човека обезбеђује Свети Дух својим посредништвом, не укидајући при том нити слободу Сина Божијег, нити, пак, слободу човека, тј. Марије Дјеве, већ их сједињује у једно, 
изражавајући слободу Марије као човека одрицањем од своје воље да буде воља Божија, што резултира јединством Божије и људске слободе у личности Сина Божијег, тј. у Христу.

Читавим својим животом Христос је и као човек показивао да је он носилац Духа Светог и да је у сталној заједници с Богом Оцем. То значи да је Христос Духом Светим, односно слободно, био у заједници с Богом Оцем. Јер, тамо где је Дух тамо је слободна заједница с Богом. Те заједнице с Богом Оцем Христос се није одреко ни по цену смрти. То је показао, пре свега, својим страдањем и својом смрћу. Страдање Христово је највећа потврда заједнице, љубави Христове према Богу Оцу и тога да је он Син Бога Оца. Јер, управо за онога смо везани као личности и од њега добијамо свој лични идентитет и постојање, за кога живот свој полажемо, односно за кога смо спремни и да умремо. Својом смрћу из љубави према Оцу, испуњавајући вољу Оца, Исус Христос је показао да је он Син Божији ${ }^{24}$. Али, Христос је и на страдање отишао бодрен од стране Светог Духа, што опет указује да делатност Светога Духа има за циљ остварење заједнице онога на коме он почива, дакле Христа, са Богом.

Смрт Христова, мећутим, има и другу димензију. Христос је умро за нас и ради нашег спасења и то слободно. Како ово треба разумети?

Само оваплоћење Христово је успоставило заједницу између Бога и створене природе и тиме је решен проблем смрти. Јер, природа је смртна и умреће једино ако остане изван заједнице с Богом. У заједници с Богом у Христу природа превазилази своју смртност. То значи да је Христос и као човек, а не само као Син Божији, био слободан од смрти. То, међутим, што се десило са природом у Христу није се десило са осталим људима као личностима. Људи, као личности, слободни су и од њихове слободе зависи да ли ће остварити заједницу с Богом и живети вечно. Људи нису просто природа, већ слободне личности. И управо је Христос зато и умро да бисмо ми, друге људске личности, могли слободно да се сјединимо с њим и да тако живимо вечно. Јер, да Христос није умро, самим оваплоћењем би се завршила историја спасења света, природа би била спашена у Христу, али остали људи не ठи. Иако би били спашени, то спасење не би било израз њихове слободе, већ би им било наметнуто. У том случају, да се то десило, не бисмо могли да говоримо о спасењу човека као личности. Јер човек је личност само кад остварује заједницу слободе с Богом, а не заједницу нужности. Христово оваплоћење је поново успоставило заједницу између Бога и створене природе, а његова смрт је омогућила људима да остваре ту заједницу у слободи али опет кроз Христа и у Христу. Отуда је са Христовом смрћу повезано и давање Светог Духа људима (уп Јн 16, 7). Јер, Дух Свети, као што смо видели, сједињује Сина Божијег са човеком.

24 Одатле је мучеништво за веру било једина истинита потврда и мерило светости у Цркви. 
Међутим, и Бог Отац је показао да је Исус Христос његов Син тиме што га је васкрсао из мртвих. Васкрсење Христово из мртвих је израз вечне, слободне љубави Бога Оца према Христу која га чини Сином Божијим, а кроз Христа и у Христу и према читавој створеној природи која је постала Тело Христово. Васкрсењем Христа Бог Отац је показао да је створена природа поново у заједници с Њим, што за природу и представља вечни живот.

Васкрсење Исуса Христа из мртвих је, међутим, делатност Бога Оца, али уз посредништво Светог Духа, о чему нам сведоче и јеванћелисти. То, такође, показује да у остварењу слободне заједнице Бога Оца са створеном природом у Христу учествује и Свети Дух. Јер, сходно учењу отаца Источне Цркве, да би постојала личност треба да је у заједници слободе са другом личношћу, али и да та друга личност слободно жели и прихвата ову заједницу, тј. љубав. И то је управо показано у васкрсењу Христовом из мртвих што је потврда да и Бог Отац слободно љуби Сина, Господа Исуса Христа, и на тај начин га чини вечном личношћу.

С друге стране, будући да Дух посредује код сваког човека који остварује заједницу са Христом, он је и залог васкрсења сваког човека у Христу. Зато је васкрсли Христос посредством Светог Духа почетак једног новог начина постојања створене природе, као Литургије, као заједнице многих у Христу, тј. као Цркве и извор је бесмртности за читаву створену природу. На овај нови начин живота вратићемо се касније.

Оно што би требало да истакнемо као закључак овог дела јесте то да је Христос својим оваплоћењем, а посебно својом добровољном смрћу омогућио да се сви људи спасу кроз остварење заједнице с њим. Смрт Христова је новина у спасењу у Христу, у односу на првог Адама, због тога што је Адам погрешио. Својим грехом, Адам је прекинуо заједницу с Богом, умро је као личност. Он се после свога греха покајао за оно што је учинио, али то покајање је могло да има плода једино после оваплоћења Христовог. Зато што само покајање Адамово није могло да успостави заједницу створене природе с Богом која је једном у њему прекинута. Заједница с Богом је онтолошке природе, а не етичке или психолошке, и сам њен прекид значи смрт. А после смрти не може бити покајања. Будући да је Христос поново успоставио заједницу с Богом, покајање као сједињење човека с Њим има смисла, и само у том случају има онтолошке последице. Мимо Христа нема никаквог покајања ${ }^{25}$.

Сада још треба размотрити на који начин ми, остали људи, постајемо причасници вечног живота кроз Христа и у Исусу Христу Сину Божијем.

25 Тајна покајања би због тога требало да буде везана за Литургију, у смислу поновног уласка човека у литургијску заједницу. 


\section{Света Еваристија је Тајна Христова - Христос}

Спасење свакога човека зависи од тога да ли ће у њему деловати личност Сина Божијег. Речју, спасење сваког човека понаособ зависи од његовог вољног поистовећења са Христом. По речима Светог Максима, Бог вечно жели да у сваком човеку делује тајна оваплоћења Христовог. Сваки човек је слободан као личност и од његове слободе зависи да ли ће да оствари заједницу са Христом и да се спасе, тј. да постане вечна личност, или неће. Ако пак то жели, на који начин то може и да оствари?

Остварење заједнице са Христом, тј. поистовећење човека са Христом, као што смо већ видели у догађају оваплоћења Христовог, подразумевало је делатност Светога Духа и вољни, слободни пристанак човека на ту заједницу.

Поистовећење многих људи са Христом, Духом Светим и на тај начин и њихово спасење од смрти, претпоставља исто тако делатност Духа и слободни пристанак човека, али и смрт Христову. По речима самога Христа: „ако зрно пшенично паднувши у земљу не умре, једно остане, а ако умре многи род донесе“. Присуство Христово на земљи по телу, пре васкрсења, као и после васкрсења, било би сметња томе да Христос постане многи и да истовремено остане један, тј. било би сметња да у многим људима делује личност Сина Божијег. Јер би на овај начин била укинута слобода људи и њихово слободно одлучивање да ли желе заједницу с Христом или не. Но, како ово треба разумети? Да Исус Христос није умро, као што смо већ нагласили, онда би једино он као човек био спашен, док би други људи били изгубљени. Могли бисмо да говоримо о спасењу природе у Христу, или о насилном спасењу људи као природе, али не и о спасењу конкретних људи као личности, будући да су људи слободни и да њихово спасење зависи од њиховог слободног пристанка, тј. слободног сједињења с Христом. Јер, ако је у Христу ослобођење од смрти, онда би са Христом требало да васкрсну сви умрли, а они који су живи да и сами постану бесмртни. То би, међутим, била наметнута бесмртност живима, ठез њиховог слободног одлучивања. Јер, нелогично би било да они који желе заједницу с Христом живе као и они који то не желе, или, пак, да једни живе, а други да умиру. Укидање смрти за Исуса Христа, тј. за човека у Христу мора бити свеопшти догађај, догађај који обухвата све људе и природу и зато он подразумева и васкрсење мртвих. Зато је свеопште васкрсење мртвих повезано са Другим и Славним доласком Господа нашег Исуса Христа. Речју, и овде се ради о слободи и заједници човека с Богом као о онтолошкој категорији. Наравно, на крају, када смрт буде дефинитивно укинута у Другом Христовом доласку, васкрснуће и они који нису хтели заједницу с Христом, али не у блаженству, већ у вечној муци и то њихово стање биће плод њихове слободне одлуке, а не наметнуто и нужно. У том слободном избору се састоји све блаженство и сва мука. 
Христова смрт, дакле, омогућава заједницу многих са њим и то на основу њихове слободе и зато се његово васкрсење поистовећује са Христовом пројавом у Евхаристији и као евхаристијска заједница многих. Јер, Васкрсли Христос се после свога васкрсења пројављује, по речима апостола очевидаца у „другом и другачијем обличју“ (уп. Мк 16, 12), тј. другачије него што се пројављивао пре смрти и васкрсења, тј. пројављује се не као један, већ као многи у Литургији и као литургијска заједница. Тачније, васкрсли Христос се пројављује у литургијској заједници са апостолима и то као онај који је началник те заједнице и онај који служи Литургију, односно који приноси сву творевину Богу Оцу. Апостоли и остали Христови ученици остварују заједницу с Христом кроз љубав према Христу и посредништвом Светог Духа. То се чини, пре свега, кроз одрицање апостола од своје воље и идењем за Христом, тј. остварењем заједнице слободе с Христом, као и давањем Светог Духа од стране Христа. Тако Христос престаје да буде јединка, већ Духом Светим постаје заједница многих, литургијска заједница. О томе нам сведоче апостоли и еванђелисти када говоре о јављањима Господа Исуса Христа њима после васкрсења, описујући их искључиво у литургијској форми (уп. Јн 20, 19 и даље; Јн 21; Лк 24; Мк 16, 14).

Ово потврђује нашу констатацију да је васкрсење Христово, тј. укидање смрти за створену природу повезано са пројавом Христовом као заједнице многих, тачније, повезано је са свеопштим васкрсењем (в. 1Кор 15, 13 и даље). Зато је евхаристијска заједница икона општег васкрсења и будућег Царства Божијег које је израз укидања смрти за целокупну творевину, иако још увек није та сама есхатолошка стварност.

С друге стране, пројава васкрслог Христа као литургијске заједнице потврђује и то да је васкрсење и вечни живот с Христом плод слободне заједнице сваког човека с Христом и дело Светога Духа.

Да би се остварила заједница с Богом у Христу, међутим, потребно је да посредује Свети Дух. Ако имамо у виду праксу Цркве да се давање Светога Духа од стране Христа везује за крштење, јер се крштењем новокрштени сједињује с Христом, тачније поистовећује се са Христом, Христос је и после своје смрти и вазнесења присутан међу нама, али сада у другом обличју, тј. кроз крштене људе. Својом делатношћу Дух Свети уз слободни пристанак, новокрштенога сједињује са Христом тако да се у новокрштеном пројављује личност Христа, Сина Божијег. Јер, као што смо већ раније видели, где год Дух делује он уводи Сина Божијег у историју, али кроз сједињење с човеком и кроз човека. Зато је било потребно да и апостоли ठуду крштени да би остварили заједницу с Христом, јер се присуство Светог Духа најпре потврђује кроз крштење којим се конституише прва заједница људи са Христом, односно литургијска заједница.

Апостоли су примили Светога Духа од васкрслог Христа и пре његовог вазнесења на небо, али не у пуноћи. Примили су Духа због њихове вере у 
Христа и њихове везе с њим упркос његовој смрти, што указује на њихову слободу и слободно заједништво с Христом, али будући да та слобода није још увек била у потпуности (на шта указује колебање апостола у вери да ли је Христос Син Божији и спаситељ света, изражена у овом периоду), то није било поистовећење са Христом у пуноћи. Тек ће то бити силаском Светога Духа на њих у дан Педесетнице. Зато је смрћу Христовом, као и вазнесењем Христовим на небо, догађајима који потврђују одсутност Исуса Христа са земље по телу, повезан и догађај слања Духа Светог од стране Бога Оца кроз Христа на апостоле и ученике Христове. Све то ради слободе и могућности да и други људи слободно Духом Светим себе поистовете са Христом.

Делатност Духа, међутим, као што смо већ видели приликом оваплоћења Христовог, огледа се у томе да он чини присутним личност Сина Божијег у историји на тај начин што га сједињује са човеком. Ову делатност Дух Свети наставља и после васкрсења и вазнесења Христовог, сједињујући многе људе са Христом, или чинећи многе да буду Христос, конституишући тако евхаристијску заједницу.

Христова личност, као заједница слободе с Богом Оцем у коју улази сада и новокрштени и усваја је као своју личност, чини новокрштеног сином Божијим по благодати. Новокрштени се, улазећи у заједницу са Сином Божијим, Христом, посредством Светог Духа, поистовећује као личност са личношћу Сина, али будући да остаје при том конкретан човек, постаје сам Христос, Син Божији по благодати. На овај начин, кроз крштење човек постаје син Божији, не престајући да буде човек. Постаје син Божији кроз поистовећење са Христом, Сином Божијим. По речима апостола, „не живим више ја, него Христос живи у мени“, или, опет, по речима Светог Јована Крститеља: „Он (Христос) треба да расте, а ја да се умањујем“ ${ }^{26}$. На антрополошком плану овде се не ради о губитку човека, већ о антрополошком максимализму. Човек од смртног бића постаје Син Божији по благодати, бесмртно и вечно биће. Да би нам ово било јасније, може нам помоћи исповедање вере у Христа од стране отаца 4. васељенског сабора. На основу саборског ороса вере, Христос је једна личност, личност Сина Божијег, иако су у њему две природе, божанска и човечанска, али је, у исто време, Христос и потпуни Бог, Син Божији и потпуни човек, као тај исти Син Божији ${ }^{27}$. Људска природа у личности Сина Божијег постала је савршени човек - Исус Христос. При томе, Христос није престао да буде Бог,

\footnotetext{
26 У овоме се састоји сва суштина подвижништва у Православној Цркви, у одрицању од своје воље, од своје природне, људске личности која нас самим тим што је природна води у смрт, и усвајањем Христове личности која нас онда води у Литургију и литургијски начин постојања. Зато је подвижништво у Цркви одувек повезано са Литургијом, на шта указује и само крштење које је основа и почетак сваког подвижништва.

27 Види орос вере 4. васељенског сабора.
} 
Син Божији. Исус Христос је и као човек Син Божији јер је у њему једна и иста личност Сина Божијег.

Новокрштеног бисмо могли да назовемо и телом Христовим, будући да је у њему личност Христова, или, тачније, будући да личност Христова присуствује на земљи и после вазнесења кроз нас и наша тела, ми сви постајемо кроз крштење Тело Христово. Новокрштени сада постоји на начин на који постоји Син Божији, не престајући да буде човек по природи. Другим речима, кроз новокрштеног се пројављује личност Сина Божијег и он се на овај начин обожује.

Обожење човека кроз крштење јесте поистовећење са Христовом личношћу, тј. са личношћу Сина Божијег и то кроз одрицање од своје воље, односно од свога људскога „Ја“ које стичемо кроз природно рођење. По речима Господа нашег Исуса Христа, „ко се не одрекне себе, не узме крст свој и не иде за мном, нема живота у себи“" ${ }^{\text {“28 }}$. Одрицањем од своје воље, тј. од своје биолошке личности као индивидуе у односу на Бога, коју човек стиче приликом природног рођења или укључујући се у друге заједнице сличног типа, и поистовећењем са вољом Божијом, тј. са личношћу Сина Божијег, човек улази у литургијску заједницу с Богом Оцем и тако Христос од јединке постаје многи, тј. постаје евхаристијска заједница, не престајући да буде један Христос.

Исус Христос је личност у којој се делатношћу Светог Духа остварује заједница између Бога Оца и човека, односно Бога Оца и створеног света, те на овај начин Исус Христос постаје први и началник читаве створене природе, преко кога се створена природа уједињује међу собом и с Богом. Јер јединство свих и целокупне творевине у Христу као началнику показује превазилажење смрти као јединство времена и простора. Разједињеност времена и простора управо је последица смрти. Да би се смрт превазишла, потребно је сједињење ових елемената, а не њихово укидање. Јер време и простор су конститутивни елементи створених бића, зато што су она створена ни из чега, и ठез њих не би ни она постојала.

Будући да време и простор не постоје мимо конкретних личности, њихово сједињење подразумева сједињење међу људима, и то кроз васкрсење оних који су умрли и јединство оних који су живи. Зато је потребно сједињење целокупне природе и оно се истински остварује једино у Христу јер је Христос у исто време у јединству с Богом и остварује јединство творевине међу собом. Ово јединство на есхатолошком плану донеће васкрсење мртвих и укидање смрти за целокупну творевину.

Пре сједињења многих са Христом, а преко њега с Богом Оцем на есхатолошком плану, јединство створене природе међу собом и с Богом

28 Одрицање од своје воље, да би у нама живела личност Христова, човек показује у чину оглашених који претходи крштењу, окретањем од запада ка истоку, одрицањем од сатане и изјавама да се сједињује са Христом. 
потребно је да се остварује и у историји. Због тога што је историја узрок постојања есхатона, тачније, ако људи сад и овде, у историји, не остваре јединство са Христом, то не могу очекивати ни у есхатону (Мидић, 2015). Јер, после смрти нема покајања. Отуда Дух Свети гради заједницу новокрштених који су се на тај начин поистоветили са Христом, у Христу и око Христа, и то, како на есхатолошком плану, који ће се остварити кроз свеопште васкрсење мртвих, тако и на историјском плану, градећи на тај начин евхаристијску заједницу око једног првог кога Дух Свети поставља. Зато је крштење у најранијој историји Цркве увек било везано за Литургију и уколико је било спојено са давањем Светога Духа, то је увек чинио први у Литургији, тј. епископ, или онај коме је епископ благословио. Кроз крштење новокрштени постаје члан литургијске заједнице, тј. крштењем Дух Свети конституише Литургију као заједницу многих у Христу као началнику, односно у епископу као икони Христовој. Отуда је Литургија у исто време икона есхатолошке стварности, тј. католичанске Цркве и та иста католичанска Црква.

После вазнесења Христовог на небо, Духом Светим Христос и даље остаје присутан у Литургији као личност, иако не и по природи. Христова личност се пројављује у сваком крштеном, али, пре свега, кроз првог и његову службу у Литургији, а та служба је остварење заједнице с другим људима кроз крштење и привођење, приношење заједнице Богу Оцу, тј. кроз приношење литургијских дарова Богу Оцу.

Први у литургијској заједници је епископ кога такође поставља Свети Дух, сједињујући га са Христом слободом Христовом која се изражава слободним пристанком, како њега, тако и свих људи, тј. крштених који су иконе Христа ${ }^{29}$. Зато је епископ као началник Литургије „на месту Хри-

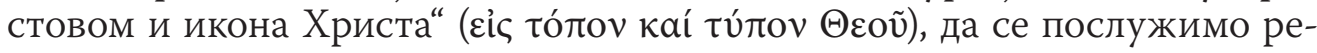
чима Светог Игнатија, који чини литургијску заједницу многих једним

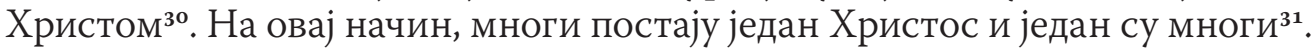

Ако се сетимо онога што смо већ говорили о личности, посебно о личности Христовој, а то је да његова личност извире из заједнице слободе с Богом Оцем, онда можемо лако закључити зашто се литургијска заједница обраћа Богу Оцу и поистовећује са Христовом личношћу. Другим речима, остварујући заједницу слободе, љубави с Богом Оцем у Литургији, сви људи у Литургији пројављују и потврђују да у њима делује личност самог Господа Христа посредством Светог Духа. Јер Христос као Син Божији јесте то што јесте у заједници слободе с Богом Оцем.

29 Уп. чин хиротоније у Православној Цркви.

зо Уп. Свети Игнатије, Смирғанима 8, 1.

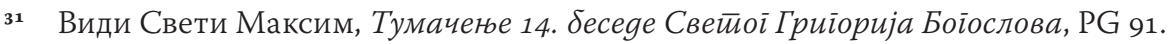


У Литургији, такође, ради се о једној личности, личности Сина Божијег, иако су многи чланови Литургије. Али сваки њен члан је, аналогно Халкидонском оросу вере, потпуни Христос, као што је Син Божији потпуни човек, кроз јединство са људском природом у Христу.

Будући да је сваки човек у Литургији икона Сина Божијег, јер се кроз крштење, тј. Духом Светим поистовећује са Христом, а Син Божији, Христос, то је што јесте у заједници с Богом Оцем, литургијска заједница треба да је окренута ка Богу Оцу. Да би се пројавила везаност литургијске заједнице за Бога Оца потребно је да у тој заједници постоји један први и да је он истовремено окренут Богу Оцу, другом човеку и природи. Зато свака литургијска заједница многих треба да има једног првог, тј. началника који ће уједињавати многе у једно тело и истовремено их сједињавати с Богом Оцем. Јер, без првог и ове његове службе сједињења других људи и природе с Богом Оцем, литургијска заједница престаје да носи лик, личност Христову, тј. Сина Божијег. Јер личност Сина Божијег не извире само из заједнице са људима и са створеном природом, већ, пре свега, извире из заједнице с Богом Оцем. Отуда је први у литургијској заједници Христос, и то као личност, на основу своје службе која га упућује ка Богу Оцу, а не по природи, и без првог и његове службе приношења целокупне заједнице људи и природе Богу Оцу не постоји нити Христос, нити Литургија, нити обожење створене природе.

Света Евхаристија је заједница оних који су умрли са Христом кроз крштење, тј. који су променили своју личност оставивши свога природног оца и који су се окренули и остварили заједницу с Богом Оцем. Ако се сетимо Христове смрти и да је он умро испуњавајући вољу Оца, што показује да Христова смрт изражава везаност Христа за Бога Оца, али да је она и због нашег спасења, онда постаје јасно зашто Литургија истовремено носи и обележје жртве и обележје васкрсења. Зато је Литургија

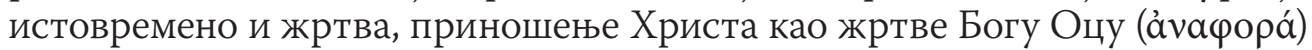
за нас, за целу заједницу, што показује да је однос чланова литургијске заједнице према Богу Оцу исти онај који је имао и има Христос према Богу Оцу, али је, у исто време, и икона васкрсења. И тај однос се остварује Духом Светим на шта у Литургији указује приношење дарова Богу Оцу

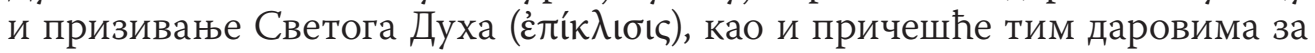
опроштај грехова и живот вечни.

На крају овог одељка могли бисмо да изведемо неколико основних закључака. Литургијска заједница постаје нови начин постојања човека и природе, тј. постаје сам Христос који је као личност Син Божији, али који у својој личности уједињује многе људе који су Тело Христово, тј. Тело Сина Божијег. Будући да је услов за крштење слобода човека као и слобода Божија која прима новокрштеног у литургијску заједницу, нови начин постојања човека у Литургији је заједница слободе, љубави Бога и човека. 
Исус Христос је глава, начелник евхаристијске заједнице многих људи и целе природе који преко њега, посредством Светог Духа долазе у заједницу с Богом Оцем. Христос је једини посредник између Бога и света и зато мимо њега нема избављења од смрти. Ту заједницу с Христом остварује Свети Дух.

Литургијска заједница је преко њеног началника који је Христос, окренута ка Богу Оцу и везана је за Бога Оца ${ }^{32}$. Ово указује на то да је лични идентитет чланова Литургије личност Сина Божијег. Јер личност добија свој идентитет у односу на личност са којом је у заједници, а то је у случају Литургије Бог Отац ${ }^{33}$. Сви чланови Литургије постају Христос, синови Божији, не престајући да буду људи. Ако, пак, новокрштени улази у Литургију и постаје њен члан, онда је јасно да се Света Литургија као заједница крштених поистовећује са Христом, тј. Евхаристија је Тајна Христова.

Љубав човека према Богу као предуслов за спасење човека од смрти апсолутно се поистовећује са љубављу човека према другом човеку. Зато што се Христос, Син Божији, у коме и кроз кога остварујемо заједницу с Богом Оцем поистовећује са литургијском заједницом. Тачније, љубав човека према другом човеку, тј. према Богу, поистовећује се са Литургијом. Изван Литургије нема правог човека, као што нема ни истинског Бога, али нема ни праве, онтолошке љубави.

Литургијска заједница човека с Богом је нови однос људи међу собом и са створеном природом, различит од биолошких заједница људи које се конституишу или природним рађањем од мужа и жене, или на било који други начин. Зато све заједнице које нису плод слободних заједница људи међу собом и са Богом Оцем у Христу, тј. које нису литургијске, не могу избавити од смрти, јер су заједнице нужности и нису заједнице с Богом Оцем, јер Бога Оца пројављује једино Христос и зато воде у смрт. Зато што је једини извор живота Бог и заједница с Њим. Литургијска заједница је вечни однос Сина Божијег са Богом Оцем који је Христос донео и пројавио у историји као човек, а кога после његовог вазнесења на небо пројављује Света Евхаристија Духом Светим као заједница многих људи у једном првом, началнику те заједнице.

Конституисање Литургије Духом Светим је ново рођење људи. Кроз крштење умире стари човек и рађа се, тј. васкрсава нови кроз заједницу и у заједници са васкрслим Христом. Овај чин није моралне природе. Не ради

32 На ово указују све евхаристијске молитве које су упућене Богу Оцу, посебно молитва приношења, анафора.

33 На истину да је литургијска заједница окренута Богу Оцу и да је везана за Бога Оца, указују све литургијске молитве, јер су упућене Богу Оцу, а посебно молитва анафоре, као и сви литургијски символи. Види молитве анафоре код Светог Василија, код Светог Јована Златоустог и др. 
се о моралном побољшању човека, у смислу да човек као јединка почиње да се придржава моралних начела у свом животу. Моралним човек може бити и мимо Литургије, иако није члан литургијске заједнице. У Литургији се ради о поистовећењу човека са Христом кроз сједињење с Њим Духом Светим, што значи сједињење с људима који су већ чланови Литургије, тј. Тела Христовог и са началником те заједнице. И управо то сједињење га избавља од смрти. Морални начин живота, тј. живот мимо литургијске заједнице, ма колико био моралан и у складу са законима правде и других закона, неизоставно води у смрт. Зато што од смрти избавља само поистовећење с Христом Сином Божијим које се остварује у заједници, и то у литургијској заједници, или другачије речено, заједници љубави.

Остварење заједнице слободе као љубави према Христу јесте ново рођење за људе које ствара Цркву као евхаристијску заједницу по икони божанског начина постојања. То се остварује, међутим, искључиво делатношћу Светога Духа. Зато што делатност Светог Духа управо ствара литургијску заједницу као заједницу слободе. Мимо ове делатности, мимо слободе, тј. стварања литургијске заједнице као сједињења с Христом Дух се не пројављује у историји. Зато се Дух Свети у Светом писму назива „Дух заједнице", по речима апостола Павла, и то литургијске заједнице. Зато се ове речи апостола Павла „и заједница Светог Духа да буде са свима вама“ односе на литургијску заједницу.

Евхаристијска заједница као Тајна Христова, као тај исти Христос, по речима Светог Максима, истовремено показује и радост васкрсења. Сви који су се кроз крштење погребли са Христом, са Христом су и васкрсли као нова твар, као литургијска заједница, као Црква. Зато је Литургија и икона Царства Божијег.

\section{Есхатон као истина Цркве}

Суочени са реалношћу смрти, без чијег укидања просто не можемо говорити о постојању човека, ни чисто у историјској реалности, васкрсење из мртвих постаје кључни догађај у животу човека и природе. По речима апостола Павла: „ако мртви неће устати онда је узалудна проповед наша и узалудна је вера ваша“ (уп. 1Кор 15, 14). Јер ако се живот завршава смрћу, онда је то трагедија, а не живот. Без наде у васкрсење и реалног догађаја васкрсења човек је трагично биће, биће ништавила без достојанства и лепоте.

Кад говоримо, међутим, о васкрсењу ту мислимо пре свега на васкрсење тела, тј. наше створене природе. Јер човек не може да постоји без тела. У томе и јесте разлика између Бога и човека, што човек има у себи тело. Личност не може да постоји без природе. Човек у Христу као личност јесте Син Божији по благодати, али он не може да постоји као човек без људског тела. Зато је потребно васкрсење из мртвих, и то васкрсење тела. 
Једини који ослобађа и који може ослободити створену природу и човека, тј. тело човечије од смрти, јесте Господ Исус Христос, Син Божији, односно личност Христова која је и носилац постојања природе, односно тела. Јер, иако личност не може да постоји без природе, односно без тела, личност је та која је узрок постојања тела. То је показано Христовим васкрсењем из мртвих. Христос као личност, као Син Божији је, међутим, вечна заједница са Оцем и Духом. У заједници слободе, љубави са Оцем, Христос је то што јесте - вечни Син Божији. Јер личност није ништа друго до заједница слободе, љубави с другом личношћу.

Чланови те и такве заједнице, тј. Христове заједнице, треба да постану сваки човек и свет у целини, да би живели вечно. А човек то може јер има слободу. И то се остварује у Литургији и кроз чланство у Литургији.

Поистовећење литургијске заједнице са Христом, и то са васкрслим Христом, показује да литургијски начин живота претставља наше васкрсење из мртвих. Тачније, литургијски начин живота постаје икона, предокус, залог догађаја свеопштег васкрсења, будући да Христос треба поново да дође када ће и сви у Христу васкрснути да више не умиру. Тај догађај, међутим, јесте дело Бога Оца и његовог благослова. Јер, да се подсетимо Христовог васкрсења, Бог Отац Духом Светим подигао је Христа из мртвих. Дакле, Христос није сам васкрсао, нити је васкрсење Христово догађај који аутоматски следи након смрти. То је дело слободе Бога Оца као израз љубави према Христу.

Аналогно овоме, свеопште васкрсење људи и природе такође је дело Бога Оца кроз Светог Духа и зависи од слободе и благовољења Бога Оца. Десиће се онда када Бог Отац буде благословио, на шта нас упућује и сам Христос кад говори о крају историје и васкрсењу мртвих. Тај догађај, међутим, ми предокушамо сад и овде у Литургији, изражавајући тиме да нам је Бог Отац већ даровао живот вечни у Христу, иако још увек није. Даровао нам га је као личностима, иако још увек по природи умиремо, али личност је та која је носилац постојања природе и ми се као личности остварујемо у Литургији, тј. у евхаристијској заједници. Зато је Литургија залог и предокус васкрсења њених чланова и то васкрсења као синова Божијих по благодати, тј. Духом Светим.

\section{Закључак}

Покушали смо да у овој краткој студији покажемо да је Црква у својој литургијској пројави нови начин постојања творевине, не институција, већ догађај слободе. Црква није скуп моралних индивидуа, већ заједница слободе, љубави међу људима у Христу који Духом Светим пројављују самог Христа на земљи као заједницу личности, као личност дакле, а не као индивидуу. Христос није индивидуа, па макар та индивидуа била и морално савршена, већ заједница личности, односно Црква. Дакле, на чему 
би требало православље да инсистира данас да би било спасавајућа сила од проблема у којима се нашао данашњи свет?

Најпре на другачијем схватању личности. За разлику од августиновског схватања личности, кападокијски хришћански оци, Василије Велики, Григорије Богослов, Григорије Ниски и други, личност су поистоветили са оgносом са другом личношћу. Личност се не изражава у индивидуализму, тј. у дистанцирању од других људи усредсређена на себе саму, на свој природни или психолошки, унутрашњи живот, тј. не изражава се као субјект који се утемељује на себи самом и на свом унутрашњем животу који води у сукоб и негацију другог, већ као однос према другом. Да би постојала личност, она неизоставно подразумева йосйојање gруїоі у односу на кога и у заједници с којим јесте то што јесте. Да би постојало, „Ја“ претпоставља једно „Ти“ и однос с њим, заједницу. У овоме много може да нам помогне савремена физика својом теоријом релативитета и квантном теоријом, која је увелико отворила врата и припремила добар терен да се чује православна реч о постојању, па и о постојању личности. Јер савремена физика указује на то, да је постојање ствар оgноса и да ништа не постоји само за сеље што није у односу са другим. Управо оно што су истицали источни оци Цркве, објашњавајући догмат о Богу који је Света Тројица. Хришћански Бог као Света Тројица је, пре свега, биће заједнице, а не монада, индивидуа. Човек, као икона Божија, да би био личност треба да је у заједници с Богом, јер је Бог апсолутно други у односу на човека као и са другим људима кроз које се једино Бог и пројављује.

Затим у схватању да је биће, тј. личност као заједница с другим израз слобоge, а не логике, односно етике. Остварење заједнице с другим као предуслов за постојање човека као личности не може бити условљено ничим, посебно не етичким нормама, осим као заједница слободе. Уколико остварујемо заједницу с другим на основу етичких принципа, затим на основу његове природе, зато што је мушко или женско, зато што је леп и тако даље, или на основу логичких претпоставки, други престаје да буде други као непоновљива личност, у пуном смислу те речи Он постаје ствар за наше искоришћавање. Слободна заједница личности се не постиже на основу природе, тј. на основу природних својстава и посматрања другог као природе и логичног закључивања о другом, већ слободном љубављу према другом која је зато слободна и јесте љубав, јер ничим није условљена, тј. зато што надилази људску природу, а самим тим и људску логику. Тачније, личност извире из зајеgнище слобоgе, љубави са другом личношћу. У овом случају, слобода једне личности се поистовећује с љубављу према другој личности, зато што без слободне заједнице личности с другом личношћу нема постојања личности. Што више воли другог, човек је све већа личност.

Истовремено, човек не може бити личност ако други с којим остварује заједницу није такође слободан и ако и он слободно не жели ту заједницу. 
Остварење заједнице с бићима која нису слободна да прихвате или одбаце ту заједницу не чини човека личношћу. То може да учини само заједница са другом личношћу која је слободна и слободно жели ту заједницу.

Овај став источних отаца о личности заснован је на вери у Бога који је Света Тројица, Отац, Син и Свети Дух и на основу објашњења Божијег откривења као Свете Тројице ${ }^{34}$.

Иако ово теоријски може неко да доводи у питање и да сматра да је ово утопија, тј. да је личност у хришћанству заиста схватана као израз заједнице слободе са другом личношћу како у контексту Божијег постојања, тако и у контексту људског постојања ${ }^{35}$, практично је ово непобитна чињеница што најбоље показује то што је хришћанство и хришћанска вера Црква. И то посебно онаквом каквом је чува источно православље у њеној литургијској пројави. Литургијска заједница је утемељена на односима слободе, љубави, а не на етичким законима и принципима. Зато Литургија, онаква каквом је чува Православна Црква, може да послужи као основ за утемељење нових друштвених односа и у савременом свету, као што је она била основ друштвених односа и у прошлости, и да послужи као парадигма за решавање многих нагомиланих проблема које пројављује савремени свет. Али и много више од тога - литургијска заједница је онтолошка заједница која ослобађа човека и природу од смрти.

Литургијско искуство Православне Цркве је посебно важно у контексту односа човека са другим човеком и природом и њега треба неизоставно пренети свету. У литургијском искуству други човек и однос слободе с њим постаје извор нашег постојања. Тај однос, тј. заједница, није условљена нити националним, нити социјалним, нити етичким, нити било којим другим карактеристикама човека. Други човек је важан зато што постоји и зато што је други у односу на нас, и заједница слободе с њим истовремено га открива као непоновљиву личност и извор нашег идентитета као непоновљиве личности.

Што се тиче природе, она се у литургијском искуству показује као неопходна за наше постојање. И то не у смислу нашег искоришћавања природе, већ у смислу чувања и бриге ради њеног вечног постојања, јер она чини саму нашу суштину, без које не може ни личност да постоји. Личност ठез природе је фантазија, као што је и природа ठез личности трулеж и ништавило. Човек се у односу на природу у литургијском доживљају појављује као свештеник у природи. У Литургији и кроз Литургију једино

34 Види Зизијулас, $1985 \delta$ и Зизијулас, 1995.

35 Било је много полемика у теолошким круговима које и данас трају, око тога да ли су свети оци видели личност као израз заједнице слободе с другом личношћу, или је то

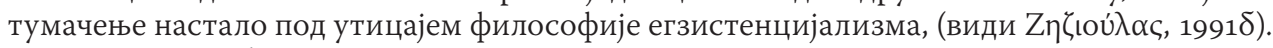
Како показује, међутим, митрополит Јован у наведеном чланку, сама евхаристијска пројава вере човека у Бога то потврђује. 
60 |Мидић, И., За јеgан gруіачији начин живойа

истински и познајемо човека и природу и циљ због чега смо створени и зашто живимо. Литургија постаје извор нашег знања о животу, метод, начин живота, али и његов циљ.

Поред тога, литургијски доживљај православног човека може бити лако прихватљив за савременог човека Запада коме се најпре и обраћамо ради решења нагомиланих проблема у свету, тим пре што је ово некад било заједничко предање и Истока и Запада.

Православна Литургија, дакле, може да послужи савременом свету као парадигма за уређење живота, како на историјском, социјалном, тако и на вечном плану, као што је она вазда то била на Истоку и један дуги временски период и на Западу, али не само на социјалном и историјском, већ и на онйолошком, вечном плану.

Црква својим постојањем има не толико социјалну важност за живот човека, у том смислу што својим постојањем показује да човек треба да живи у заједници слободе с другим човеком и с природом која га окружује да би био личност и тиме решио проблем зла на етичком и социјалном плану, тј. у историји, већ много дубљу, онтолошку важност. Православни литургијски доживљај постојања света неодвојив је од његове вечне перспективе, јер је Литургија, пре свега, предокус вечног постојања човека и света. 


\section{Литература}

De Ružmon, D. (2011). Ljubav i Zapad. Beograd: Službeni glasnik.

Zizioulas, J. (1985a). Being as communion. London: Darton, Longman and Tod Ltd.

Зизијулас, J. (1985б). Од маске до личности. Боіословље, 1-2, 17-4о.

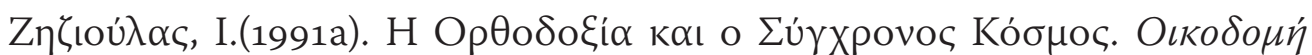

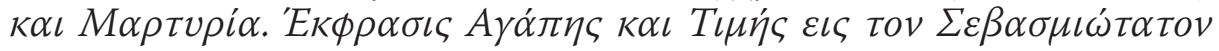

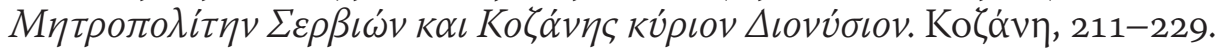

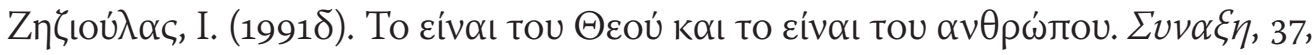
$11-36$.

Зизијулас, J. (1995). Допринос кападокијских отаца хришћанској мисли. У: Православна йеолоіија (стр. 7-17). Београд: Православни Богословски факултет.

Ziziulas, J. (2012). Ontology and Ethics. Саборност̄, 6, 1-14.

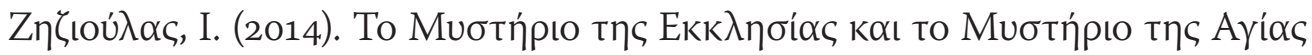

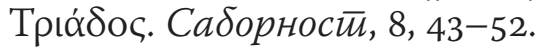

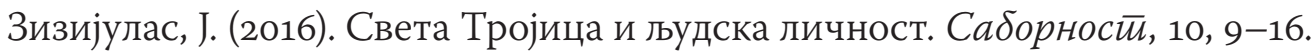

Јевтић, А. (1979). Теолошко дело Светог Василија Великог између „Никејаца“ и „Источних“. Теолошки йоїлеgu, 4, 177-192.

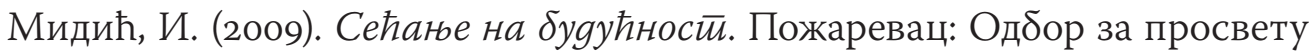
и културу Епархије браничевске.

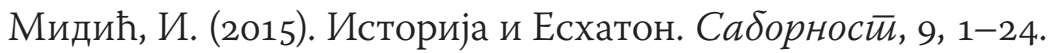

Свети Атанасије Велики, О овайлоћењу Сина Божијеї.

Свети Василије, О Духу свейом, 18 (PG 32, 194s).

Свети Григорије, Теолошка Secega 3, 16.

Свети Игнатије, Смирғанима 8, 1.

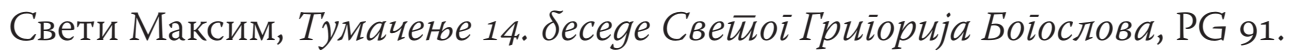




\section{Ignatije Midić}

University of Belgrade, Faculty of Orthodox Theology, Belgrade

\section{Towards a Different Mode of Life}

The modern mode of life has brought many problems to mankind. It threat1 ens to endanger existence, both man and nature. But, is this, modern mode of existence of man and the entire creation the only option for us? Is this living in accordance with the logic of the modern civilization the only option? Is there an alternative? Who should offer the alternative? In this study, the author develops a thesis that the Church is the reality which should offer the alternative, and the new way of life today.

Key words: modern civilization, Church, Liturgy, Christ, communion, eschatology.

Датум пријема чланка: 4. 6. 2017.

Датум прихватања чланка за објављивање: 10. 10. 2017. 